Muhammad Fikry Anshori | Globalisasi Society 5.0 Jepang: Studi Kasus Hasil

Pencarian Google di Luar Jepang Tahun 2019

Article

\title{
Globalisasi Society 5.0 Jepang: Studi Kasus Hasil Pencarian Google di Luar Jepang Tahun 2019 \\ Muhammad Fikry Anshori ${ }^{1}$ \\ ${ }^{1}$ Kajian Wilayah Jepang, Sekolah Kajian Stratejik dan Global, Universitas Indonesia
}

\section{SUBMISSION TRACK}

$\begin{array}{ll}\text { Recieved } & : \text { 15 February } 2020 \\ \text { Final Revision } & : 25 \text { April } 2020 \\ \text { Available Online } & : \text { 30 May } 2020\end{array}$

KEYWORD

Globalization, Google, Information and

Communications Technology (ICT), Japan,

Society 5.0

\section{KATA KUNCI}

Globalisasi, Google, Jepang, Society 5.0,

Teknologi Informasi dan Komunikasi (TIK)

\section{CORRESSPONDENCE}

E-mail : muhammad.fikry01@ui.ac.id

\section{A B S T R A C T}

This article seeks to describe the spread of Japan's Society 5.0 topic outside Japan based on Google's search results in 2019. Japan's Society 5.0 needs to be discussed because the global aspect of Japan's Society 5.0, namely the spread via the internet and Google, has not been researched widely. Even though, the Government of Japan committed as a role model for the world with Society 5.0. The method used in this article is a case study with data from Google Trends. The concept used is the globalization from Thomas Friedman. The results of this article show that the topic of Japan's Society 5.0 has attracted foreign public attention in several countries such as Indonesia, Malaysia, India, and the United States. Then, the public in these countries also used Google to find out topics related to Japan's Society 5.0. For example, the topics of society, industry, the industrial revolution, and Industry 4.0. The spread of Japan's Society 5.0 topic in various countries can be stated in line with Thomas Friedman's argumentation on globalization which is centered on Information and Communications Technology (ICT) development.

\section{A B S T R A K}

Artikel ini berupaya untuk mendeskripsikan penyebaran topik Society 5.0 Jepang di luar Jepang berdasarkan hasil pencarian Google pada tahun 2019. Society 5.0 Jepang perlu untuk dibahas karena aspek global dari Society 5.0 Jepang yaitu penyebaran melalui internet dan Google belum terlalu dikaji secara luas. Padahal, Pemerintah Jepang memiliki komitmen untuk menjadi percontohan bagi dunia dengan Society 5.0. Metode yang digunakan dalam artikel ini adalah studi kasus dengan data dari Google Trends. Konsep yang digunakan adalah globalisasi dari Thomas Friedman. Hasil artikel ini memperlihatkan topik Society 5.0 Jepang menjadi perhatian publik asing di beberapa negara seperti Indonesia, Malaysia, India, dan Amerika Serikat. Lalu, publik di negara-negara tersebut juga menggunakan Google untuk mencari tahu topik yang terkait dengan Society 5.0 Jepang. Contohnya adalah topik masyarakat, industri, revolusi industri, dan Industry 4.0. Penyebaran topik Society 5.0 Jepang di berbagai negara dapat dinyatakan sejalan dengan argumentasi globalisasi dari Thomas Friedman yang berpusat pada perkembangan Teknologi Informasi dan Komunikasi (TIK). 
Muhammad Fikry Anshori | Globalisasi Society 5.0 Jepang: Studi Kasus Hasil

Pencarian Google di Luar Jepang Tahun 2019

\section{Pendahuluan}

Globalisasi adalah istilah yang menjadi sangat populer pasca Perang Dingin. Istilah globalisasi digunakan oleh khalayak umum untuk menggambarkan kondisi dunia yang melebur menjadi ruang ekonomi dan sosial bersama tidak terbatas. Globalisasi juga dikenal sebagai suatu proses yang disebabkan oleh perkembangan teknologi informasi dan komunikasi (TIK). Sehingga berdampak pada peningkatan hubungan interdependensi di dunia. ${ }^{1}$

Interdependensi ini dapat terlihat dari pengguna internet di dunia yang terus meningkat sejak tahun 2005 (Lihat Tabel 1). Jumlah pengguna internet pada tahun 2005 hanya $16,8 \%$ dari populasi dunia. International Telecommunication Union (ITU) memperkirakan ada 4,1 miliar orang yang menggunakan internet pada tahun 2019. Jumlah tersebut setara dengan 53,6\% populasi dunia. $^{2}$

Tabel 1: Proporsi Pengguna Internet di Dunia $^{3}$

\begin{tabular}{ll}
\hline Tahun & $\begin{array}{l}\text { Persentase } \\
\text { Pengguna }\end{array}$ \\
\hline 2005 & $16,8 \%$ \\
\hline 2006 & $18,4 \%$ \\
\hline 2007 & $20,6 \%$ \\
\hline 2008 & $23,1 \%$ \\
\hline 2009 & $25,8 \%$ \\
\hline 2010 & $29,3 \%$ \\
\hline 2011 & $31,8 \%$ \\
\hline 2012 & $34,8 \%$ \\
\hline 2013 & $37,0 \%$ \\
\hline 2014 & $39,1 \%$ \\
\hline 2015 & $41,5 \%$ \\
\hline 2017 & $44,8 \%$ \\
\hline 2018 & $49,0 \%$ \\
\hline 2019 & $51,4 \%$ \\
\hline
\end{tabular}

1 T. Diez et al., Key Concepts in International Relations (London: SAGE, 2011), 78-79.

2 International Telecommunication Union. Measuring Digital Development: Facts and Figure 2019 (Geneva: ITU Publication, 2019), 1.

${ }^{3}$ Ibid.
Google adalah aplikasi internet berupa mesin pencarian daring. Google merupakan salah satu inovasi TIK yang pertama kali dikembangkan oleh Larry Page dan Sergey Brin pada tahun 1998. Satu tahun setelah berdiri, Google diakses oleh 3,5 juta pengguna per hari. Untuk saat ini, Google diakses oleh sekitar 3,5 miliar pengguna per hari. ${ }^{4}$ Pertumbuhan pengguna yang pesat membuat Google menjadi bagian yang tidak terpisahkan dari Internet. ${ }^{5}$

Globalisasi dan perkembangan TIK mendorong negara-negara untuk terlibat secara aktif. Salah satu negara tersebut adalah Jepang. Jepang merupakan negara yang maju secara ekonomi dan menjadi ahli di bidang teknologi. Produk elektronik merupakan salah satu komoditas ekspor Jepang. Kapasitas yang demikian membuat Jepang termasuk ke dalam lima besar negara dengan Gross Domestic Product (GDP) terbesar. Ditambah lagi, Jepang adalah negara dengan total pengguna internet mencapai $92 \%$ dari populasi. Kondisi tersebut membuat Jepang menempati posisi kelima dalam peringkat negara dengan penetrasi internet terbesar. ${ }^{6}$

Pada 23 Januari 2019, Perdana Menteri Jepang Shinzo Abe menyampaikan pidato yang berjudul "Toward a New Era of "Hope-Driven Economy"'" (Menuju Era Baru "Ekonomi yang didorong Harapan") di World Economic Forum. Dalam pidato tersebut, disampaikan visi masyarakat masa depan bernama Society 5.0. Shinzo Abe menyatakan dalam Society 5.0 bukan lagi modal tetapi data yang menghubungkan dan mendorong segala aspek kehidupan. Berbagai layanan yang terintegrasi inovasi

\footnotetext{
4 InternetLiveStats, "Google Search Statistics," Internet Live Stats, https://internetlivestats.com/ google-search-statistics (diakses 30 Januari 2020).

5 D. A. Vise, The Google Story: Inside the Hottest Business, Media, and Technology Success of Our Time (London: Pan Macmillan, 2005), 1.

${ }^{6}$ Central Intelligence Agency, "Japan," The World Factbook, https://www.cia.gov/library/publications/ the-world-factbook/geos/ja.html (diakses 3 Februari 2020).
} 
Muhammad Fikry Anshori | Globalisasi Society 5.0 Jepang: Studi Kasus Hasil

Pencarian Google di Luar Jepang Tahun 2019

TIK seperti kesehatan dan pendidikan akan menjadi lebih terjangkau bagi masyarakat. Permasalahan sosial seperti ketimpangan ekonomi juga dapat dikurangi dengan hal tersebut. Sehingga dapat membangun kehidupan yang lebih baik. ${ }^{7}$

Pemerintah Jepang menyatakan akan berperan aktif dalam mengembangkan Society 5.0 di dunia. Jepang berkomitmen untuk menjadi panutan bagi negara lain dengan Society 5.0. Society 5.0 bagi Pemerintah Jepang adalah visi yang berorientasi pengoptimalan inovasi teknologi agar berkontribusi bagi perbaikan kehidupan masyarakat global. Berbagai masalah sosial kontemporer saat ini dan di masa mendatang memerlukan inovasi teknologi sebagai solusi. Lebih lanjut, Jepang juga berupaya untuk membuktikan pembangunan ekonomi dapat terus terjadi di tengah masalah sosial seperti aging society (peningkatan jumlah lansia dan penurunan angka kelahiran) melalui implementasi Society 5.0. ${ }^{8}$

Topik Society 5.0 Jepang sudah menjadi bahasan akademis di beberapa bidang kaji. Antropologi membahas prospek human-centeredness dari Society 5.0 dibandingkan masyarakat Jepang terdahulu. ${ }^{9}$ Ilmu Sejarah memberikan perhatian pada keterkaitan periode perkembangan dari industri sejak abad ke-

\footnotetext{
${ }^{7}$ Ministry of Foreign Affairs of Japan, "Speech by Prime Minister Abe at the World Economic Forum Annual Meeting Toward a New Era of "HopeDriven Economy" (23 January 2019)," Ministry of Foreign Affairs of Japan, https://www.mofa.go.jp/ecm/ec/

page4e_000973.html (diakses 3 Februari 2020); UNESCO, "Japan pushing ahead with Society 5.0 to overcome chronic social challenges," UNESCO, https://en.unesco.org/news/japan-pushing-aheadsociety-50-overcome-chronic-social-challenges (diakses 3 Februari 2020).

8 Government of Japan, "Technology", The Government of Japan, https://www.japan.go.jp/ technology/ (diakses 19 Juni 2020).

${ }_{9}$ M. E. Gladden, "Who Will Be the Members of Society 5.0? Towards an Anthropology of Technologically Posthumanized Future Societies," Social Sciences 8, no. 5 (2019): 148.
}

20 dengan Society 5.0 Jepang. ${ }^{10}$ Teknik Informatika dan Elektro mengkaji implementasi teknologi terbaru untuk penduduk di kota-kota Jepang yang relevan dengan Society 5.0. ${ }^{11}$ Ilmu Ekonomi, Bisnis, dan Manajemen membahas tentang perencanaan alur produksi barang, risiko terhadap buruh dan modal, serta transformasi digital industri yang menjadi implikasi dari Society 5.0 Jepang. ${ }^{12}$

Berbagai kajian di atas masih terbatas dalam cakupan lokal atau dalam negeri Jepang itu sendiri. Aspek global dari Society 5.0 Jepang belum terlalu diangkat sebagai bahasan utama. Keberadaan konektivitas internet dan aplikasi Google memungkinkan visi Society 5.0 dari Jepang dapat dengan mudah dicari informasinya oleh publik asing di luar Jepang. Lebih lanjut, Pemerintah Jepang sedang berupaya menjadi percontohan bagi negara negara lain dengan mengembangkan implementasi visi Society 5.0. Oleh karena itu, artikel ini berupaya untuk dapat mendeskripsikan penyebaran topik Society 5.0 Jepang di luar Jepang berdasarkan hasil pencarian Google pada tahun 2019.

\footnotetext{
${ }^{10}$ A. G. Pareira dan T. M. Lima, "Society 5.0 as a Result of the Technological Evolution: Historical Approach," International Conference on Human Interaction and Emerging Technologies (2019): 700-705; M. Nagahara. "A Research Project of Society 5.0 in Kitakyushu, Japan." 2019 IEEE Conference on Control Technology and Applications (CCTA) (2019): 10.1109/CCTA.2019.8920449.

${ }^{11}$ Y. Shiroshi, K. Uchiyama, dan N. Suzuki, "Better Actions for Society 5.0: Using AI for EvidenceBased Policy Making That Keeps Humans in the Loop," Computer 52, no 11 (2019): 73-78

12 K. Matsuda et al. "Technologies of Production with Society 5.0." 2019 6th International Conference on Behavioral, Economic and SocioCultural Computing (BESC) (2019): 10.1109/BESC48373.2019.8963541; K. Fukuda, "Science, technology and innovation ecosystem transformation toward society 5.0." International Journal of Production Economics (2019): https://doi.org/10.1016/j.ijpe.2019.07.033; Onday, O.. "Japan's Society 5.0: Going Beyond Industry 4.0." Business and Economics Journal 10, no 2. (2019): 389.
} 
Muhammad Fikry Anshori | Globalisasi Society 5.0 Jepang: Studi Kasus Hasil

Pencarian Google di Luar Jepang Tahun 2019

\section{Metode Penelitian}

Metode yang digunakan dalam artikel ini adalah studi kasus. Studi kasus berguna dalam penelitian yang melakukan investigasi terhadap fenomena tunggal atau spesifik. $^{13}$ Teknik pengumpulan data yang digunakan adalah studi berbasis internet. Tema data yang dikumpulkan ada empat yaitu lokasi penyebaran topik Society 5.0 di luar Jepang berdasarkan hasil pencarian Google tahun 2019, tren topik Society 5.0 di luar Jepang berdasarkan hasil pencarian Google tahun 2019, kata kunci yang digunakan oleh publik asing (bukan Jepang) untuk mencari topik Society 5.0 di Google tahun 2019, serta topik lain yang juga dicari oleh publik asing ketika mencari topik Society 5.0 Jepang di Google tahun 2019. Sumber data yang digunakan untuk mengumpulkan tema data tersebut adalah Google Trends. Google Trends merupakan salah satu fitur dari Google yang memungkinkan penggunanya untuk mengeksplorasi berbagai kata kunci yang sedang dicari di Google dalam periode dan lokasi tertentu. ${ }^{14}$ Kapasitas tersebut membuat data dari Google Trends dapat dikatakan valid dan reliabel untuk memenuhi tujuan penulisan artikel ini. Teknik analisis data yang digunakan adalah time-series. ${ }^{15}$

\footnotetext{
13 J. Gerring, "What is Case Study and What is It Good for?," American Political Science Review 40, no. 3 (2004): 341-342.

14 Google, "The Homepage Explained," Google Support, https://support.google.com/trends/answer/ 6248105 ?hl=en\&ref_topic $=6248052$ (diakses 28 Januari 2020).

${ }^{15}$ R. K Yin, Case Study Research and Application: Designs and Methods (London: SAGE, 2018), 144. Time-series adalah teknik analisis dalam studi kasus untuk mendeskripsikan keterhubungan peristiwa yang dapat berupa: 1) suatu peristiwa terjadi sebelum atau sesudah peristiwa lain, 2) suatu peristiwa diikuti secara bersamaan oleh peristiwa lain, 3) suatu peristiwa mengikuti peristiwa lain setelah jangka waktu tertentu, atau 4) suatu peristiwa berbeda secara substansial di periode lain.
}

\section{Hasil dan Diskusi}

Globalisasi, Teknologi Informasi dan Komunikasi, serta Society 5.0 Jepang

Definisi sederhana dari globalisasi adalah perluasan, pendalaman, dan percepatan keterhubungan di seluruh dunia. ${ }^{16}$ Globalisasi dapat didefinisikan secara luas sebagai serangkaian proses yang mewujudkan perubahan dalam hubungan dan transaksi sosial menjadi luas, intensif, cepat, dan berdampak. Itu berarti globalisasi membuat aliran, jaringan, aktivitas, interaksi, dan kuasa yang lintas benua dan antar kawasan. ${ }^{17}$ Selain itu, globalisasi dapat didefinisikan secara sempit sebagai integrasi ekonomi dunia dalam bentuk peningkatan keterhubungan berbagai negara melalui perdagangan, arus finansial, dan investasi asing oleh perusahaan multinasional. ${ }^{18}$

Berbagai definisi di atas masih diperdebatkan keakuratannya dalam menggambarkan globalisasi. Dengan hal tersebut, Jan A. Scholte menyatakan globalisasi lebih baik dipahami sebagai konfigurasi ulang geografi sosial yang ditandai dengan pertumbuhan hubungan transplanetary (melintasi keseluruhan bumi) dan supraterritorial (melampaui batasan wilayah) antar manusia. Lebih lanjut, globalisasi juga saling berkaitan dengan pertumbuhan struktur produksi, pemerintahan, identitas, dan pengetahuan. Sehingga, globalisasi mendorong pertumbuhan area dan bentuk baru interaksi yang berpusat pada aktor non-negara,

\footnotetext{
${ }^{16}$ A. McGrew, "Globalization and Global Politics," dalam The Globalization of World Politics: An Introduction to International Relations, ed. J. Baylis et al. (New York: Oxford University Press, 2014), 16.

${ }^{17}$ D. Held et al., Global Transformations: Politics, Economics and Culture (Cambridge: Polity Press, 1999), 16.

${ }^{18}$ R. Gilpin. Global Political Economy (Princeton: Princeton Press, 2001), 364.
} 
identitas non-nasional, dan pengetahuan non-rasional. ${ }^{19}$

Selain dengan definisi, George Ritzer dan Paul Dean menyatakan globalisasi dapat dipahami juga dengan metafora arus. Metafora arus menggambarkan globalisasi sebagai perpindahan manusia, benda, informasi, dan tempat yang diakibatkan oleh semakin berkurangnya hambatan global. Globalisasi merupakan arus yang bersifat saling terhubung, ke segala arah, berlawanan, atau berbalik. Kemudian, globalisasi memiliki berbagai jenis arus antara lain arus ekonomi, arus budaya dan kebudayaan, arus manusia, arus lingkungan, serta arus teknologi informasi dan komunikasi. Dengan sifat dan jenis arus tersebut, globalisasi menjadi pengalaman sehari-hari yang berlangsung di berbagai tempat. Globalisasi sudah dianggap menjadi hal yang lumrah di berbagai kalangan masyarakat. ${ }^{20}$

Teknologi informasi dan komunikasi (TIK) adalah salah satu arus utama terkini yang mendukung perkembangan globalisasi. Sumbangan TIK untuk globalisasi adalah mengurangi hambatan ruang dan waktu. Sehingga, dunia seolaholah mengerucut dan berbagai kegiatan menjadi berlangsung secara cepat. Dua macam TIK yang sangat berpengaruh dalam globalisasi adalah internet dan media sosial. $^{21}$ Internet merupakan fasilitas komunikasi yang didesain untuk menghubungkan komputer maupun perangkat komputasi lainnya agar dapat saling bertukar informasi digital. Internet adalah infrastruktur yang menghadirkan layanan komunikasi dasar dalam menyampaikan informasi. ${ }^{22}$ Media sosial

19 J. A. Scholte, Globalization: A Critical Introduction (New York: Palgrave Macmillan, 2005), 8.

${ }^{20}$ G. Ritzer dan P. Dean, Globalization: A Basic Text (Oxford: John Wiley \& Sons, 2015), 6-8.

${ }^{21}$ G. Ritzer dan P. Dean, Globalization: A Basic Text (Oxford: John Wiley \& Sons, 2015), 238.

${ }^{22}$ D. Clark, "An Insider's Guide to the Internet," MIT Computer Science and Artificial Intelligence Laboratory, https://groups.csail.mit.edu/ana/ adalah aplikasi internet berupa arena digital yang memungkinkan penggunanya untuk saling berpartisipasi dan berinteraksi secara aktif. $^{23}$ Contoh media sosial antara lain Facebook, Twitter, dan Instagram.

Argumentasi globalisasi tidak terlepas dari TIK dinyatakan juga oleh Thomas Friedman. Friedman berpendapat TIK membuat dunia yang "sudah kecil menjadi lebih kecil lagi” (menghilangkan hambatan jarak) dan secara bersamaan "memipihkan" (menghilangkan hambatan struktural) arena interaksi. Keberadaan TIK juga mengubah karakteristik dari globalisasi itu sendiri. Globalisasi pada awalnya hanya mengglobalnya negara dan perusahaan yang berasal dari Eropa dan Amerika. Kehadiran TIK seperti Internet membuat globalisasi memiliki karakteristik yang memungkinkan berbagai macam aktor untuk berkolaborasi dan berkompetisi secara global. Dengan kata lain, TIK mengembangkan globalisasi menjadi proses yang terjangkau dan dapat diikuti oleh siapa saja. Hal tersebut menjadikan globalisasi lebih inklusif, beragam, dan demokratis. $^{24}$

Friedman melakukan elaborasi lebih lanjut pendapatnya dengan memaparkan sepuluh dorongan pembentuk era baru globalisasi yang terjadi di akhir abad ke-20 dan awal abad ke-21. Berikut adalah ulasannya.

Dorongan pertama adalah robohnya Tembok Berlin di tahun 1989 dan perilisan sistem operasi komputer Windows $3.0 \mathrm{di}$ tahun 1992. Runtuhnya Tembok Berlin mewakili perubahan tatanan dunia. Sedangkan Windows 3.0 menandai inovasi komputer pribadi. Dorongan selanjutnya adalah pengembangan jaringan internet dan

Publications/PubPDFs/An-Insiders-Guide-to-theInternet.pdf (diakses 29 Januari 2020).

23 J. Manning, "Social Media, Definition and Classes of," dalam Encyclopedia of Social Media and Politics, ed. K. Harvey. (Thousand Oaks: SAGE, 2014), 1158-1159.

${ }^{24}$ T. L. Friedman, The World is Flat: A Brief History of the Twenty-First Century (New York: Picador, 2007), 3-50. 
Muhammad Fikry Anshori | Globalisasi Society 5.0 Jepang: Studi Kasus Hasil

Pencarian Google di Luar Jepang Tahun 2019

hadirnya aplikasi peramban (browser)

Netscape di tahun 1995. Internet dan aplikasi browser membentuk konektivitas baru bagi pengguna komputer di berbagai belahan dunia. Dorongan ketiga adalah standardisasi infrastruktur fisik dan perangkat lunak komputer pada tahun 1998. Standardisasi tersebut mendukung kelancaran arus kerja layanan internet di seluruh dunia. Lalu, dorongan keempat adalah hadirnya blog sebagai aplikasi yang memfasilitasi pengguna internet untuk membuat, membagikan, dan mengomentari berbagai macam konten (berita, cerita, gambar, dll) di tahun $1999 .{ }^{25}$

Dorongan kelima adalah munculnya kesadaran pengguna untuk tetap memperbarui perangkat komputer yang diakibatkan oleh bug dalam sistem penghitungan kalender pada tahun 2000. Kemudian, dorongan keenam adalah bergabungnya Tiongkok ke World Trade Organization (WTO) di tahun 2001. Keanggotaan Tiongkok memberikan dinamika baru dalam kompetisi impor, ekspor, dan investasi global. Dorongan ketujuh adalah penggunaan TIK oleh pasar swalayan Amerika Serikat bernama WalMart untuk meningkatkan efisiensi pengelolaan perpindahan dan penyimpanan produk skala global di tahun 2002. Dorongan tersebut kemudian disusul oleh dorongan serupa berupa penggunaan TIK oleh perusahaan jasa pengiriman barang United Parcel Service (UPS) untuk meningkatkan efisiensi alur pengiriman barang skala global di tahun 2003. Dorongan kesembilan adalah munculnya dua aplikasi pencarian daring yaitu Google dan Yahoo pada tahun 2004. Google dan Yahoo adalah aplikasi yang dapat memberikan beragam informasi dari internet bagi penggunanya. Dorongan terakhir adalah hadirnya perangkat komunikasi pribadi yang canggih, kecil, ringan, dan mudah dibawa kemana-mana

25 T. L. Friedman, The World is Flat: A Brief History of the Twenty-First Century (New York: Picador, 2007), 51-126. bernama Personal Digital Assistance (PDA) di tahun $2005 .^{26}$

Pernyataan Friedman mengenai sepuluh dorongan tersebut menjadikannya diposisikan sebagai pemikir positif terhadap globalisasi. Friedman menekankan globalisasi bisa memberikan keuntungan yang sangat banyak bagi berbagai pihak. Globalisasi menghadirkan kesempatan meningkatkan untuk memperbaiki kesejahteraan masyarakat seluruh dunia di abad ke-21. Sehingga, globalisasi terus berlanjut sebagai proses transformasi luar biasa yang relevan bagi masyarakat di dunia. Penekanan tersebut membuat pendapat Friedman berkontribusi dalam melawan berbagai pendapat negatif mengenai dampak globalisasi dari gerakan anti-globalisasi. Pendapat Friedman sebagai pemikiran positif globalisasi membuat pemikiran anti-globalisasi salah kaprah. ${ }^{27}$

Perkembangan TIK yang mendukung globalisasi terus berlanjut hingga kini. Inovasi TIK semakin canggih dan melampaui TIK yang sudah disebutkan dalam sepuluh dorongan Friedman. Inovasi tersebut antara lain ponsel pintar (smartphone), Artificial Intelligence (AI), mahadata (big data), dan Internet of Things (IoT). Ponsel pintar merupakan perangkat dalam genggaman yang memiliki bermacam fitur komputer dan multimedia. $^{28}$ AI adalah perangkat keras dan perangkat lunak komputer yang memiliki struktur, perilaku, kapabilitas, fungsi, dan prinsip layaknya manusia rasional. ${ }^{29}$ Mahadata merupakan informasi bernilai yang bersifat kompleks, memiliki

26 T. L. Friedman, The World is Flat: A Brief History of the Twenty-First Century (New York: Picador, 2007), 126-199.

27 A. Jones, Globalization: Key Thinkers (Cambridge: Polity Press, 2010), 130-131.

28 Global Knowledge, "Smartphone Explained," MicroComputer Resources, http://www.mcrinc.com/ Documents/Newsletters/201104_Hill_Smartphones. pdf (diakses 30 Januari 2020).

${ }_{29}$ P. Wang, "What do You Mean by "AI"?," Frontiers in Artificial Intelligence and Applications (2008): 362. 
Pencarian Google di Luar Jepang Tahun 2019

ukuran yang besar, dan diperoleh dengan cepat. ${ }^{30}$ IoT adalah jaringan antara berbagai benda fisik sehari-hari dengan menggunakan internet untuk saling berhubungan. $^{31}$

Keberadaan inovasi TIK tersebut menempati posisi penting bagi masyarakat. Inovasi TIK dapat dikatakan mencerminkan perkembangan masyarakat. Masyarakat dapat menggunakan TIK untuk tujuan mengimbangi isu sosial yang perlu untuk diselesaikan dengan tetap memastikan perkembangan ekonomi. Dengan kata lain, masyarakat dapat secara cerdas memiliki ketangkasan, mobilitas, reaktivitas, serta kemampuan untuk beradaptasi dan mengintegrasikan TIK. Pendekatan penggunaan TIK yang demikian adalah kunci dari Society 5.0 Jepang. ${ }^{32}$

Jepang membuat visi Society 5.0 berdasarkan lima taksonomi perkembangan masyarakat dalam sejarah yaitu masyarakat berburu, masyarakat bertani, masyarakat industri, masyarakat informasi, dan masyarakat pintar. Masyarakat berburu merupakan masyarakat yang hidup berdampingan dengan alam untuk memenuhi kebutuhan pada 13.000 tahun sebelum masehi (SM). Masyarakat bertani adalah masyarakat yang hidup dengan mengembangkan irigasi dan pemukiman pada 13.000 tahun SM hingga akhir abad ke-18. Masyarakat industri adalah masyarakat periode akhir abad ke-18 hingga akhir abad ke-20 yang membuat berbagi inovasi skala industri. Inovasi tersebut berupa mesin-mesin yang dapat mengolah produk secara massal. Masyarakat informasi adalah masyarakat

\footnotetext{
30 Oracle, "What is Big Data?," Oracle, https://www. oracle.com/big-data/guide/what-is-bigdata.html (diakses 30 Januari 2020).

${ }^{31}$ K. K. Patel dan S. M. Patel, "Internet of ThingsIOT: Definition, Characteristics, Architecture, Enabling Technologies, Application \& Future Challenges," International Journal of Engineering Science and Computing 6, no. 5 (2016): 6122.

${ }^{32}$ B. Salgues, Society 5.0: Industry of the Future, Technologies, Methods and Tools (Hoboken: John Wiley \& Sons, 2018), 1-21.
}

periode akhir abad ke-20 hingga awal abad ke-21 yang menemukan komputer untuk mengembangkan distribusi informasi secara luas. Sedangkan masyarakat pintar adalah Society 5.0 Jepang itu sendiri yang akan tercapai dalam waktu dekat. ${ }^{33}$

Society 5.0 adalah salah satu upaya implementasi pembangunan berkelanjutan yang hendak dipromosikan Jepang kepada negara lain. Inovasi TIK terkini yang hadir di industri dan kehidupan sehari-hari akan membentuk nilai dan layanan baru. Hal ini akan memberikan kenyamanan dan keberlanjutan bagi masyarakat. Jepang meyakini Society 5.0 dapat terwujud karena mahadata yang dikumpulkan oleh IoT akan diolah menjadi AI baru dan akan mencapai seluruh lapisan masyarakat. Keterhubungan inovasi TIK tersebut akan memberikan solusi untuk kehidupan manusia yang lebih baik. Ditambah lagi, Jepang menyatakan Society 5.0 akan mengubah dunia di beberapa bidang yaitu layanan kesehatan, mobilitas, infrastruktur, dan teknologi finansial. Orientasi Society 5.0 yang mengoptimalkan inovasi TIK untuk berbagai bidang tersebut akan membantu dalam menghadapi dan menyelesaikan permasalahan yang ada di masyarakat. Sehingga dapat mewujudkan ekonomi masyarakat yang lebih baik dengan memperbaiki produktivitas dan menciptakan pasar baru. ${ }^{34}$

Pemerintah Jepang menyatakan Jepang memiliki dua keunggulan dalam mewujudkan Society 5.0 yaitu keberadaan mahadata yang melimpah dan monozukuri. Penggunaan mahadata sudah dioptimalkan di Jepang untuk beberapa bidang seperti ekonomi, industri, dan kesehatan. Beragam program dan layanan untuk penduduk Jepang juga dirumuskan, dijalankan, dan dievaluasi secara sistematis dengan mahadata. Jepang memberikan contoh

\footnotetext{
${ }^{33}$ Ibid.

${ }^{34}$ Government of Japan, "Realizing Society 5.0," The Government of Japan, https://www.japan.go.jp/ abenomics/_userdata/abenomics/pdf/society_5.0.pdf (diakses 3 Februari 2020).
} 
Muhammad Fikry Anshori | Globalisasi Society 5.0 Jepang: Studi Kasus Hasil

Pencarian Google di Luar Jepang Tahun 2019

berupa operasionalisasi data pasien untuk pengembangan layanan kesehatan masyarakat serta manufaktur peralatan rumah sakit. Sedangkan monozukuri adalah tradisi pengembangan produk bermutu tinggi yang dianut dalam industri Jepang. Aspek utama dalam monozukuri adalah penelitian dan pengembangan yang dilakukan secara berkelanjutan. Hal ini juga mendukung keunggulan industri dalam produksi dan distribusi ke konsumen. Jepang meyakini dapat memperkenalkan solusi mutakhir untuk berbagai isu global dengan tradisi dan pengalaman tersebut. ${ }^{35}$

\section{Penyebaran Topik Society 5.0 Jepang di Luar Jepang berdasarkan Google pada tahun 2019}

Hasil pengumpulan data dari Google Trends adalah empat macam informasi yang terdiri dari interest by region, interest over time, related queries dan related topics. Interest by region adalah informasi tentang lokasi yang menjadi tempat suatu topik paling populer selama periode tertentu. Interest over time adalah informasi yang mewakili minat pencarian relatif suatu topik untuk wilayah dan periode tertentu. Related queries adalah berbagai term populer untuk mencari suatu topik di wilayah dan periode tertentu. Related topics adalah berbagai topik lain yang juga dicari ketika mencari suatu topik tertentu. Google memuat empat macam informasi tersebut dalam Google Trends menggunakan skala dari 0 hingga 100. Dengan 0 mewakili bobot paling rendah atau tidak ada bobot serta 100 mewakili bobot paling tinggi. ${ }^{36}$ Berikut adalah uraian dan visualisasi dari data yang dikumpulkan.

Di 2019, topik Society 5.0 Jepang menjadi perhatian publik asing di empat negara: 1) Indonesia, 2) Malaysia, 3) India,

\footnotetext{
35 Ibid.

${ }^{36}$ Google, "Explore Society 5.0 Worldwide 201901-01 to 2019-12-31," Google Trends, https://trends.google.com/trends/explore?date $=2019$ $-01-01 \% 202019-12-31 \& q=\% 2 F g \% 2 F 11$ fzkvd6z1 (diakses 6 Februari 2020).
}

dan 4) Amerika Serikat (Lihat Gambar 1). Alasan utama yang membuat topik Society 5.0 populer dicari di empat negara tersebut jika dikaitkan dengan globalisasi secara sempit adalah relasi ekonomi. Indonesia, Malaysia, India, dan Amerika Serikat memiliki hubungan bilateral yang baik dan aktif dengan Jepang di bidang ekonomi.

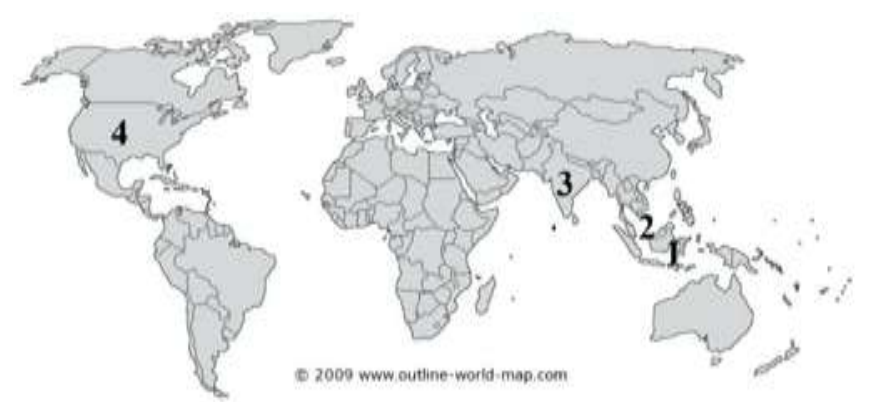

Gambar 1: Interest by Region Topik Society 5.0 di Luar Jepang

Hubungan ekonomi Indonesia dan Jepang fokus pada tiga bidang yaitu perdagangan, investasi, dan kerja sama ekonomi. Di perdagangan, Indonesia dan Jepang adalah mitra strategis. Komoditas yang diimpor oleh Jepang dari Indonesia antara lain minyak bumi, gas alam, batu bara, udang, dan tekstil. Di sisi lain, Indonesia mengimpor mesin dan suku cadang kendaraan, produk plastik dan kimia, serta peralatan listrik. Lalu untuk investasi, terdapat kurang lebih seribu perusahaan Jepang yang beroperasi di Indonesia. Perusahaan tersebut mempekerjakan lebih dari 32 ribu penduduk Indonesia. Jepang menjadi salah satu negara yang menyediakan lapangan pekerjaan terbesar. Terakhir, kerja sama ekonomi yang dilakukan Indonesia dan Jepang adalah pinjaman, bantuan hibah, dan kerja sama teknik. Indonesia merupakan negara penerima bantuan pembangunan terbesar dari Jepang terutama untuk infrastruktur. Bantuan pembangunan tersebut ditujukan kepada pemerintah dan masyarakat Indonesia. ${ }^{37}$

\footnotetext{
${ }^{37}$ Kedutaan Besar Jepang di Indonesia, "Hubungan Bilateral Indonesia-Jepang," Kedutaan Besar Jepang di Indonesia, https://www.id.emb-
} 
Muhammad Fikry Anshori | Globalisasi Society 5.0 Jepang: Studi Kasus Hasil

Pencarian Google di Luar Jepang Tahun 2019

Malaysia dan Jepang sudah sejak tahun 1957 menjalankan hubungan bilateral di bidang ekonomi. Hubungan bilateral tersebut kemudian diperkuat dengan disepakatinya Japan-Malaysia Economic Partnership Agreement pada tahun 2005. Dengan hal tersebut, Malaysia dan Jepang menjadi mitra ekonomi yang dekat. Malaysia mengekspor komoditas minyak bumi, gas alam, perlengkapan elektronik, serta kayu dan mebel. Sedangkan komoditas yang diekspor oleh Jepang adalah produk elektronik, kendaraan, mesin, serta produk besi dan baja. Jepang juga merupakan negara investor terbesar di Malaysia. Jepang sudah mengoperasikan 1.300 perusahaan yang kebanyakan beroperasi di sektor industri. Sama halnya dengan Indonesia, Malaysia menerima pinjaman, bantuan hibah, dan kerja sama teknik dari Jepang. Bidang yang menerima tiga hal tersebut adalah pendidikan, pangan, kesehatan, transportasi, dan budaya. Bantuan di setiap bidang diberikan langsung ke tingkat pemerintah dan masyarakat. ${ }^{38}$

India dan Jepang memiliki hubungan ekonomi dalam sektor investasi, sumber daya manusia, dan bantuan. Pada sektor investasi, Jepang sudah mengoperasikan 1.305 perusahaan di India. India dan Jepang memiliki visi yang sama dalam mendukung

japan.go.jp/ birel_id.html (diakses 8 Februari 2020); Ministry of Foreign Affairs of Japan, "Exchange of Notes in Fiscal Year 2019: Grant Aid by Region," Ministry of Foreign Affairs of Japan, https://www.mofa.go.jp/

policy/oda/page22e_000878.html (diakses 8

Februari 2020); Ministry of Foreign Affairs of Japan, "Exchange of Notes in Fiscal Year 2019: Loan Aid by Region," Ministry of Foreign Affairs of Japan,

https://www.mofa.go.jp/policy/oda/page22e_000891 .html (diakses 8 Februari 2020).

38 Embassy of Japan in Malaysia, "Overview of Japan-Malaysia Relationship," Embassy of Japan in Malaysia, https://www.my.emb-japan.go.jp/English/ bilateral/Overview_bilateral.htm (diakses 8 Februari 2020); Ministry of Foreign Affairs of Japan, “Diplomatic Bluebook 2019," Diplomatic Bluebook, https://www.mofa.go.jp/files/000527162.pdf (diakses 8 Februari 2020).

keberlangsungan investasi. Oleh karena itu, India dan Jepang berupaya untuk membangun lingkungan bisnis berupa area industri yang memiliki regulasi jelas. Jepang juga membantu pengembangan sumber daya manusia dengan menyelenggarakan pelatihan bagi 30.000 orang India agar memiliki keahlian di bidang manufaktur. Jepang berharap pelatihan dapat membantu pengembangan industri di India itu sendiri dan lulusan pelatihan tersebut juga memiliki keinginan untuk melanjutkan studi di Jepang. Terakhir, Jepang memberikan bantuan luar negeri ke India untuk sektor transportasi umum. India sejak tahun 2018 sedang mengembangkan kereta cepat dan model yang dijadikan dasar adalah kereta cepat Shinkansen dari Jepang. ${ }^{39}$

Hubungan ekonomi Amerika Serikat dan Jepang berjalan di dua bidang yaitu perdagangan dan investasi. Jepang mengekspor kendaraan bermotor dan suku cadang, mesin, dan komputer ke Amerika Serikat. Sedangkan Amerika Serikat mengekspor pesawat, perlengkapan medis, instrumen ilmiah dan optik, serta hasil pertanian. Lalu, Jepang memproyeksikan perdagangan ke depan dengan Amerika Serikat yang akan berbeda secara komoditas. Jepang akan mulai mengimpor produk komputer Amerika Serikat juga karena pertumbuhan TIK terkini. Beralih pada bidang investasi, dua negara tersebut saling menanamkan investasi di sektor industri. Perusahaan di Amerika Serikat yang berafiliasi dengan Jepang sudah membuka lapangan pekerjaan untuk 720.000 penduduk Amerika Serikat. Dengan hal tersebut, investasi Jepang di Amerika Serikat memberikan kontribusi juga untuk pertumbuhan ekonomi Amerika

\footnotetext{
${ }^{39}$ Ministry of Foreign Affairs of Japan, "Japan-India Relations," Ministry of Foreign Affairs of Japan, https://www.mofa.go.jp/region/asiapaci/india/data.html (diakses 8 Februari 2020); Ministry of Foreign Affairs of Japan, "Diplomatic Bluebook 2019," Diplomatic Bluebook, https://www.mofa.go.jp/files/000527162.pdf (diakses 8 Februari 2020).
} 
Muhammad Fikry Anshori | Globalisasi Society 5.0 Jepang: Studi Kasus Hasil

Pencarian Google di Luar Jepang Tahun 2019

Serikat. Lebih lanjut, kontribusi tersebut melebihi perusahaan asing lainnya yang beroperasi di Amerika Serikat. ${ }^{40}$

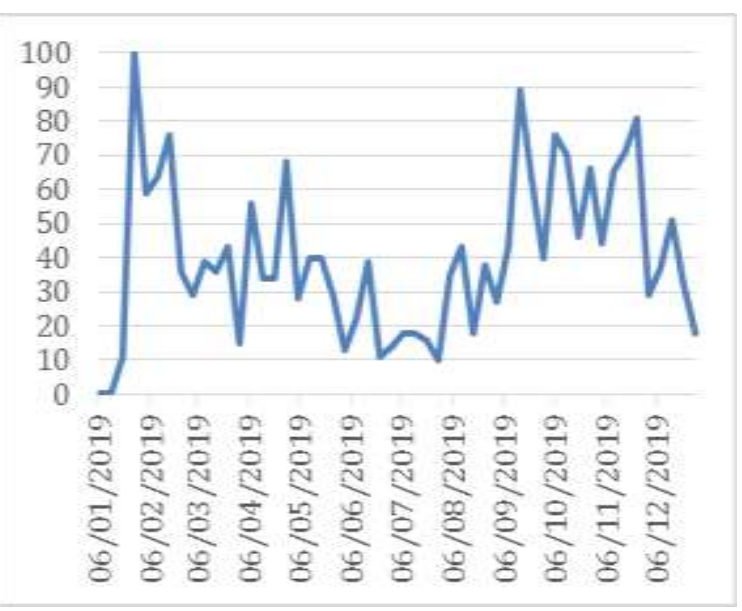

Gambar 1. Interest Over Time dari Hasil Pencarian Google Society 5.0 di Indonesia tahun 2019

Gambar 1 menggambarkan tren pencarian Google topik Society 5.0 oleh publik Indonesia di 2019. Publik Indonesia paling banyak mencari topik Society 5.0 di tiga tanggal berikut: 1) 20-27 Januari 2019, 2) $8-15$ September 2019,3$)$ dan 17-24 November 2019. Pada tanggal-tanggal tersebut, terdapat pemberitaan daring mengenai Society 5.0 Jepang di Google Indonesia. Pemberitaan daring yang terbit di 20-27 Januari 2019 membahas tentang pengenalan Society 5.0 Jepang dan visi Society 5.0 yang mampu mengubah

\footnotetext{
40 Ministry of Foreign Affairs of Japan, "JapanUnited States of America Relations," Ministry of Foreign Affairs of Japan, https://www.mofa.go.jp/na/na1/ us/page23e_000329.html (diakses 8 Februari 2020); Ministry of Foreign Affairs of Japan, "Is it true that Japan imports only agricultural products from the United States?," Ministry of Foreign Affairs of Japan, https://www.mofa.go.jp/region/namerica/us/q\&a/ trend/3.html (diakses 8 Februari 2020); Ministry of Foreign Affairs of Japan, "Japanese industries have been setting up a lot of companies in the United States. Do they benefit the U.S. economy?," Ministry of Foreign Affairs of Japan, https://www.mofa. go.jp/region/namerica/us/q\&a/trend/5.html (diakses 8 Februari 2020).
}

kehidupan sehari-hari dengan digitalisasi. ${ }^{41}$ Untuk tanggal 8-15 September 2019, pemberitaan daring kebanyakan bertemakan strategi yang dapat dilakukan oleh Indonesia untuk menghadapi Society 5.0 Jepang. Strategi tersebut fokus pada kualitas sumber daya manusia dan inovasi layanan bisnis. ${ }^{42}$ Lalu, pemberitaan daring yang terbit di 17-24 November memiliki tema tentang ekspektasi di regional Asia Tenggara untuk menghadapi Society 5.0 Jepang serta implikasi Society 5.0 yang bisa membuat masyarakat menjadi menerima atau menolak TIK. ${ }^{43}$

41 D. Mayasari, "Mengenal Society 5.0,
Transformasi Kehidupan yang Dikembangkan Jepang," Times Indonesia, https://www.timesindonesia.co.id/read/ news/197889/mengenal-society-50-transformasikehidupan-yang-dikembangkan-jepang (diakses 9 Februari 2020); W. B. Santoso, "Jelajahi Era 5.0, Jepang Sudah Lama Tinggalkan Industri 4.0," Sindo News, https://autotekno.sindonews.com/read/ 1374004/207/jelajahi-era-50-jepang-sudah-lamatinggalkan-industri-40-1548594777 (diakses 9 Februari 2020).

42 T. Aulia, "Denna Rainyana: One Site for All Dutabisnis Jadi Solusi Layanan Korporasi untuk Society 5.0," Times Indonesia, https://www. timesindonesia.co.id/read/news/228952/dennarainyana-one-site-for-all-dutabisnis-jadi-solusilayanan-korporasi-untuk-society-50 (diakses 9 Februari 2020); Y. Winosa, "Bangun SDM Industri Kompeten, Kemenperin Dorong Kualitas Institut," Warta Ekonomi, https://www.wartaekonomi.co.id/ read246639/bangun-sdm-industri-kompeten-

kemenperin-dorong-kualitas-institut (diakses 9 Februari 2020).

43 E. Prima, "BPPT Berharap Forum ASEAN Jadi Momentum Open Government dan Data," Tempo, https://tekno.tempo.co/read/1275090/bppt-berharapforum-asean-jadi-momentum-open-governmentdan-data/full\&view=ok (diakses 9 Februari 2020); A. Fitria, "Ketua Aspikom: Manusia Saat Ini Terbagi Jadi Dua Kelompok," IDN Times, https://www.idntimes.com/news/indonesia/auliafitria/ketua-aspikom-manusia-saat-ini-terbagi-jadidua-kelompok/full (diakses 9 Februari 2020). 
Muhammad Fikry Anshori | Globalisasi Society 5.0 Jepang: Studi Kasus Hasil

Pencarian Google di Luar Jepang Tahun 2019

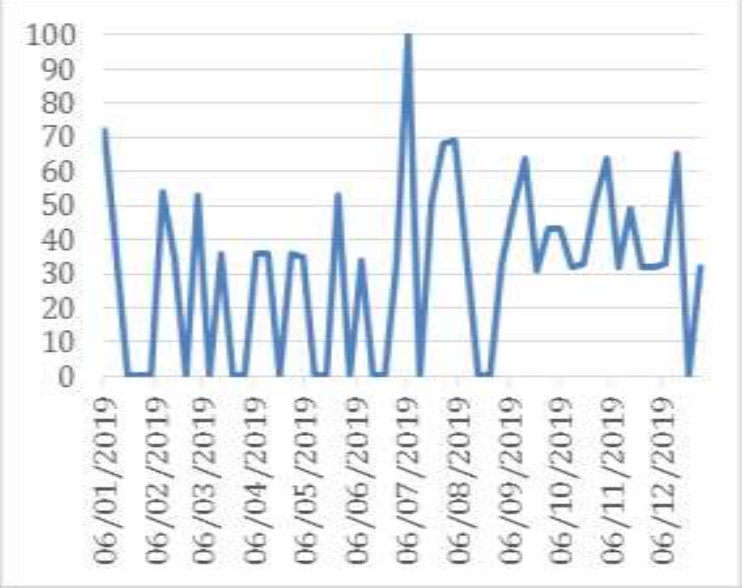

Gambar 2. Interest Over Time dari Hasil Pencarian Google Society 5.0 di Malaysia tahun 2019

Tren pencarian Google topik Society 5.0 oleh publik Malaysia di 2019 dapat dilihat pada Gambar 2. Publik Malaysia paling banyak mencari topik Society $5.0 \mathrm{di}$ tiga tanggal berikut: 1) 1-7 Juli 2019, 2) 16 Januari 2019, 3) dan 29 Juli - 4 Agustus 2019. Pemberitaan daring tanggal 1-7 Juli 2019 membahas tentang kewirausahaan akan memiliki kesempatan yang luas untuk berkembang dengan masuknya era Society 5.0. ${ }^{44}$ Kemudian, pemberitaan daring yang terbit di 1-6 Januari 2019 membahas tantangan yang akan dihadapi pendidikan tinggi. Keberadaan Society 5.0 mendorong perlunya peningkatan kualitas dan kecakapan yang dimiliki mahasiswa Malaysia. ${ }^{45}$ Beralih ke tanggal $29 \mathrm{Juli}-4$ Agustus 2019, pemberitaan daring membahas tentang strategi Malaysia menghadapi Society 5.0 dengan industri dan pembangunan berkelanjutan. Strategi

T. J. Yee, "Wild Digital 2019: Mindful Entrepreneurs Can Catalyze Great Change," Digital News Asia, https://www.digitalnewsasia.com/digitaleconomy/wild-digital-2019-mindful-entrepreneurscan-catalyse-great-change (diakses 9 Februari 2020).

45 S. Rozana dan Z. Mustafa, "What lies ahead in 2019 for higher education?," New Straits Times, https://www.nst.com.my/education/2019/01/446228/ what-lies-ahead-2019-higher-education (diakses 9 Februari 2020). tersebut perlu didukung dengan riset ilmiah di bidang teknologi dan lingkungan untuk menghasilkan inovasi yang relevan. ${ }^{46}$

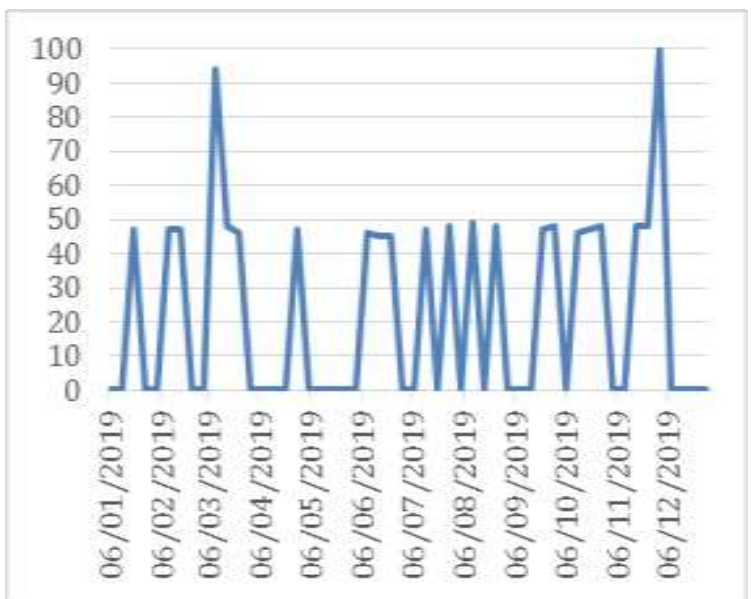

Gambar 3. Interest Over Time dari Hasil Pencarian Google Society 5.0 di India tahun 2019

Figur 3 adalah visualisasi tren pencarian Google topik Society 5.0 oleh publik India di 2019. Publik India paling banyak mencari topik Society 5.0 di tiga tanggal berikut: 1) 24 November - 1 Desember 2019, 2) 3-10 Maret 2019, 3) dan 4-11 Agustus 2019. Pemberitaan pada 24 November - 1 Desember 2019 membahas Combined Exhibition of Advanced Technologies (CEATEC). CEATEC adalah pameran yang diadakan di Tokyo, Jepang untuk memperkenalkan inovasi TIK terbaru sebagai implementasi dari Society 5.0. ${ }^{47}$ Selanjutnya, pemberitaan di 3-10 Maret 2019 membahas investasi Jepang di India dalam rangka Society 5.0.

\footnotetext{
46 The Sun Daily, "Of collaborations and insights: Industry Insights 2019 themed Advocates of Society 5.0," The Sun Daily, https://www.thesundaily.my/ supplement/education/of-collaborations-andinsights-YN1179652 (diakses 9 Februari 2020); S. Kumar, "Deploy science now to reach sustainable growth goals," New Straits Times, https://www.nst.com.my/ opinion/columnists/2019/07/508534/deploy-sciencenow-reach-sustainable-growth-goals (diakses 9 Februari 2020).

47 Japan Brandvoice, "Society 5.0 Town Turns Heads At Japan's CEATEC Tech Show," Forbes, https://www.forbes.com/sites/japan/2019/11/28/soci ety-50-town-turns-heads-at-japans-ceatec-techshow/\#2c1ca01d542f (diakses 11 Februari 2020).
} 
Muhammad Fikry Anshori | Globalisasi Society 5.0 Jepang: Studi Kasus Hasil

Pencarian Google di Luar Jepang Tahun 2019

Investasi tersebut ditujukan untuk pengembangan TIK pada sektor kesehatan di India. Kesehatan merupakan sektor penting dalam Society 5.0 Jepang. ${ }^{48}$ Terakhir, tema dari pemberitaan pada 4-11 Agustus 2019 adalah pengenalan visi Society 5.0 dan pengaruhnya terhadap masyarakat. $^{49}$

Tren pencarian Google topik Society 5.0 oleh publik Amerika Serikat di 2019 dapat dilihat pada Figur 4 (Halaman Selanjutnya). Publik Amerika Serikat paling banyak mencari topik Society 5.0 di tiga tanggal berikut: 1) 27 Januari - 3 Februari 2019, 2) 10-17 November 2019, 3) dan 16-23 Juni 2019. Pemberitaan daring pada 27 Januari - 3 Februari 2019 membahas Society 5.0 Jepang membuka kesempatan baru bagi pengusaha di masa mendatang. ${ }^{50}$ Tema pemberitaan yang berbeda terlihat pada 10-17 November 2019. Pada tanggal tersebut, pemberitaan membahas Society 5.0 adalah upaya Jepang untuk menjadi pemimpin global. Jepang dapat berkontribusi untuk inovasi TIK di tengah persaingan antara Amerika Serikat dan China. ${ }^{51}$ Beralih pada16-23 Juni 2019, pemberitaan daring membahas tentang pembangunan berkelanjutan yang dapat

\footnotetext{
48 Our Bureau, "Japan throws open doors of manufacturing, healthcare sectors for Indian firms," The Hindu Business Line, https://www. thehindubusinessline.com/companies/japan-throwsopen-doors-of-manufacturing-healthcare-sectorsfor-indian-firms/article26472642.ece (diakses 11 Februari 2020).

${ }^{49}$ V. P. Kafle, "Toward Society 5.0," myRepublica, https://myrepublica.nagariknetwork.com/news/towa rd-society-5-0/ (diakses 11 Februari 2020).

${ }^{50} \mathrm{M}$. Minevich, “Japan's 'Society 5.0' initiative is a road map for today's entrepreneurs," TechCrunch, https://techcrunch.com/2019/02/02/japans-society-50-initiative-is-a-roadmap-for-todays-entrepreneurs/ (diakses 11 Februari 2020).

${ }^{51}$ I. Bremmer dan H. Nakanishi, "Critical for Japan to take global leadership role," The Japan News, https://the-japan-

news.com/news/article/0006157173 (diakses 11 Februari 2020).
}

diwujudkan dengan kolaborasi publikprivat dalam kerangka Society 5.0. ${ }^{52}$

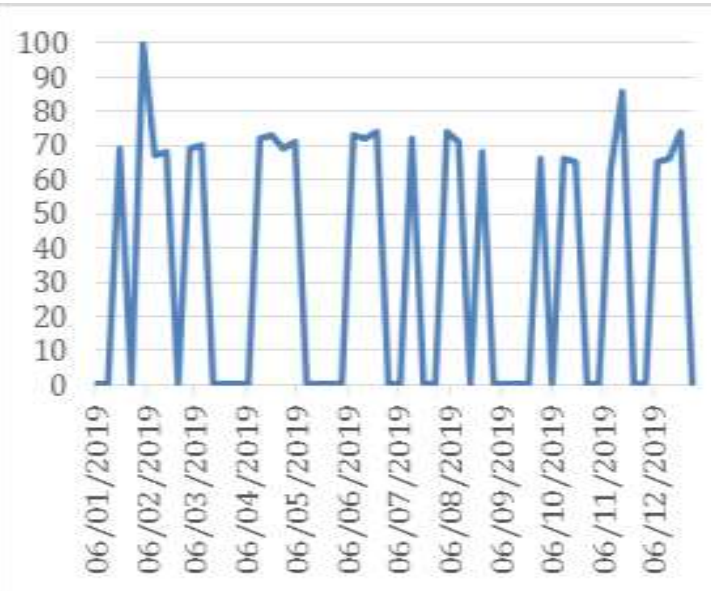

\section{Gambar 4. Interest Over Time dari Hasil Pencarian Google Society 5.0 di Amerika Serikat tahun 2019}

Hasil tren pencarian Google terhadap topik Society 5.0 dari publik Indonesia, Malaysia, India, dan Amerika Serikat memperlihatkan keberadaan tiga macam tema pemberitaan daring yang muncul di masing-masing negara. Tema pertama adalah pengenalan Society 5.0 Jepang. Society 5.0 merupakan visi baru yang sedang dijalankan oleh Jepang dan publik negara lain dapat dikatakan masih awam akan hal tersebut. Tema kedua adalah kesempatan dan tantangan yang dihadirkan Society 5.0 Jepang. Pemberitaan daring di setiap negara membahas berbagai bidang yang dapat optimal berkembang maupun terhambat dengan adanya Society 5.0 Jepang. Bidang tersebut antara lain teknologi, pendidikan, bisnis, lingkungan, dan kesehatan. Tema ketiga adalah strategi yang dapat digunakan untuk menghadapi Society 5.0. Strategi yang dibahas antara lain pengembangan sumber daya manusia, inovasi layanan pendidikan dan bisnis, serta kolaborasi pemerintah dan swasta.

52 S. Yamaguchi, "Collaboration among stakeholders key to achieving development goals," Nikkei Asian Review, https://asia.nikkei.com/Opinion/ Collaborationamong-stakeholders-key-to-achieving-developmentgoals (diakses 11 Februari 2020). 
Muhammad Fikry Anshori | Globalisasi Society 5.0 Jepang: Studi Kasus Hasil

Pencarian Google di Luar Jepang Tahun 2019

Kemudian, strategi tersebut juga tidak hanya fokus pada dalam negeri saja tetapi juga kawasan.

Publik Indonesia mencari topik Society 5.0 Jepang di Google menggunakan tiga kata kunci: 1) "society 5.0", 2) "society 5.0 adalah", dan 3) "society 5.0 pdf". ${ }^{53}$ Hal tersebut berbeda dengan publik Malaysia yang hanya menggunakan kata kunci "society 5.0". 54 Selanjutnya, kata kunci

53 Google, "relatedQueries Indonesia," Google Trends,

https://trends.google.com/trends/api/widgetdata/relat edsearches/csv?req $=\% 7 \mathrm{~B} \% 22$ restriction $\% 22 \% 3 \mathrm{~A} \%$ 7B\%22geo\%22\%3A\%7B\%22country\%22\%3A\%22 ID $\% 22 \% 7 \mathrm{D} \% 2 \mathrm{C} \% 22$ time\%22\%3A\%222019-01-

01\%202019-12-31\%22\%2C\%22originalTime

RangeForExploreUr1\%22\%3A\%222019-01-

01\%202019-12-31\%22\%2C\%22complexKeywords

Restriction\%22\%3A\%7B\%22keyword\%22\%3A\%5

B\%7B\%22type $\% 22 \% 3 \mathrm{~A} \% 22 \mathrm{ENTITY} \% 22 \% 2 \mathrm{C} \% 2$

2value $\% 22 \% 3 \mathrm{~A} \% 22 \% 2 \mathrm{Fg} \% 2 \mathrm{~F} 11 \mathrm{fzkvd} 6 \mathrm{z} 1 \% 22 \% 7$

D\%5D\%7D\%7D\%2C\%22keywordType\%22\%3A\%

22QUERY\%22\%2C\%22metric\%22\%3A\%5B\%22T

OP $\% 22 \% 2 \mathrm{C} \% 22 \mathrm{RISING} \% 22 \% 5 \mathrm{D} \% 2 \mathrm{C} \% 22$ trendin essSettings \%22\%3A\%7B\%22compareTime $\% 22 \% 3$ A\%222018-01-01\%202018-12-

$31 \% 22 \% 7 \mathrm{D} \% 2 \mathrm{C} \% 22$ request

Options $\% 22 \% 3 \mathrm{~A} \% 7 \mathrm{~B} \% 22$ property $\% 22 \% 3 \mathrm{~A} \% 22 \%$ $22 \% 2 \mathrm{C} \% 22$ backend $\% 22 \% 3 \mathrm{~A} \% 22 \mathrm{IZG} \% 22 \% 2 \mathrm{C} \% 2$ 2category $\% 22 \% 3 \mathrm{~A} 0 \% 7 \mathrm{D} \% 2 \mathrm{C} \% 22$ language $\% 22 \% 3$ A\%22en\%22\%7D\&token=APP6_UEAAAAAXj2D Ffng2gofcBrLOABLZD3oikIfFPLw\&tz=-420 (diakses 6 Februari 2020).

54 Google, "relatedQueries Malaysia," Google Trends,

https://trends.google.com/trends/api/widgetdata/relat edsearches/csv?req $=\% 7 \mathrm{~B} \% 22$ restriction $\% 22 \% 3 \mathrm{~A} \%$ 7B\%22geo $\% 22 \% 3 \mathrm{~A} \% 7 \mathrm{~B} \% 22$ country $\% 22 \% 3 \mathrm{~A} \% 22$ MY\%22\%7D\%2C\%22time\%22\%3A\%222019-01-

01\%202019-12-31\%22\%2C\%22originalTimeRange ForExploreUr1\%22\%3A\%222019-01-01\%202019$12-$

$31 \% 22 \% 2 \mathrm{C} \% 22$ complexKeywordsRestriction $\% 22$ $\% 3 \mathrm{~A} \% 7 \mathrm{~B} \% 22$ keyword $\% 22 \% 3 \mathrm{~A} \% 5 \mathrm{~B} \% 7 \mathrm{~B} \% 22$ type $\% 22 \% 3 \mathrm{~A} \% 22 \mathrm{ENTITY} \% 22 \% 2 \mathrm{C} \% 22$ value $\% 22 \% 3 \mathrm{~A}$ $\% 22 \% 2 \mathrm{Fg} \% 2 \mathrm{~F} 11 \mathrm{fzkvd6z} 1 \% 22 \% 7 \mathrm{D} \% 5 \mathrm{D} \% 7 \mathrm{D} \% 7 \mathrm{D}$ $\% 2 \mathrm{C} \% 22$ keywordType $\% 22 \% 3 \mathrm{~A} \% 22 \mathrm{QUERY} \% 22$ $\% 2 \mathrm{C} \% 22$ metric $\% 22 \% 3 \mathrm{~A} \% 5 \mathrm{~B} \% 22 \mathrm{TOP} \% 22 \% 2 \mathrm{C} \%$ 22RISING $\% 22 \% 5 \mathrm{D} \% 2 \mathrm{C} \% 22$ trendinessSettings $\% 2$ 2\%3A\%7B\%22compareTime\%22\%3A\%22201801-01\%202018-12-31\%22\%7D\%2C\%22request Options $\% 22 \% 3 \mathrm{~A} \% 7 \mathrm{~B} \% 22$ property $\% 22 \% 3 \mathrm{~A} \% 22 \%$ $22 \% 2 \mathrm{C} \% 22$ backend $\% 22 \% 3 \mathrm{~A} \% 22 \mathrm{IZG} \% 22 \% 2 \mathrm{C} \% 2$ 2category $\% 22 \% 3 \mathrm{~A} 0 \% 7 \mathrm{D} \% 2 \mathrm{C} \% 22$ language $\% 22 \% 3$ A\%22en\%22\%7D\&token=APP6_UEAAAAAXj2D

yang digunakan oleh publik India dan Amerika Serikat tidak dapat diketahui. Google tidak punya cukup data mengenai kata kunci yang digunakan publik India dan Amerika Serikat untuk mencari Society 5.0 Jepang. ${ }^{55}$ Hal menarik dari kata-kata kunci yang sudah diulas adalah kata kunci dari publik Indonesia. Publik Indonesia mencoba untuk mencari tahu definisi dari Society 5.0 Jepang. Lebih lanjut, pencarian menggunakan kata kunci yang ditambahkan ekstensi file "pdf" menunjukan publik Indonesia mencari referensi Society 5.0 yang dapat dikatakan valid. Ekstensi file "pdf" diasosiasikan sebagai dokumen resmi atau karya ilmiah.

Publik dari empat negara di atas melakukan eksplorasi topik lain yang terkait Society 5.0 Jepang dalam Google. Publik Indonesia mencari tahu tentang topik masyarakat, industri, revolusi, Industry 4.0, dan Fourth Industrial Revolution. ${ }^{56}$ Sedangkan, publik Malaysia mencari tahu mengenai topik masyarakat, orang Jepang, Jepang, dan bahasa Jepang. ${ }^{57}$

fugxNCedRG49U3fyKPyp96cAH3dw\&tz=-420

(diakses 6 Februari 2020).

${ }^{55}$ Google, "Explore Society 5.0 India 2019-01-01 to 2019-12-31," Google Trends, https://trends.google. $\mathrm{com} /$ trends/explore?date $=2019-01-01 \% 202019-12$ $31 \&$ geo $=\mathrm{IN} \& \mathrm{q}=\% 2 \mathrm{Fg} \%$ 2F11fzkvd6z1 (diakses 6 Februari 2020); Google, "Explore Society 5.0 United States 2019-01-01 to 2019-12-31," Google Trends, https://trends.google.com/trends/explore?date=2019 $-01-01 \% 202019-12-31$ \&geo=US\&q= $\% 2 F g \% 2$

F11fzkvd6z1 (diakses 6 Februari 2020).

${ }^{56}$ Google, "Explore Society 5.0 Indonesia 2019-0101 to 2019-12-31," Google Trends, https://trends.google.

com/trends/explore?date=2019-01-01\%202019-12$31 \&$ geo $=$ ID\&q=\%2Fg\%2F11fzkvd6z1 (diakses 6 Februari 2020); K. Schwab, The Fourth Industrial Revolution, (Geneva: World Economic Forum), 710. Industry 4.0 atau Fourth Industrial Revolution adalah penggunaan teknologi baru seperti robot, kecerdasan buatan, percetakan $3 \mathrm{D}$, dan pengeditan genetik yang berdampak pada keseluruhan disiplin ilmu, ekonomi, dan industri.

${ }^{57}$ Google, "Explore Society 5.0 Malaysia 2019-0101 to 2019-12-31," Google Trends, https://trends.google.

com/trends/explore?date=2019-01-01\%202019-12- 
Publik India hanya fokus mencari topik masyarakat dan Jepang. ${ }^{58}$ Lebih lanjut, pencarian topik lebih sempit dilakukan oleh publik Amerika Serikat yang fokus pada topik masyarakat saja. ${ }^{59}$ Hasil eksplorasi topik lain di Google memperlihatkan aspek yang dicari oleh publik luar negeri setelah mengetahui Society 5.0 Jepang. Publik Indonesia memiliki rasa ingin tahu pada aspek industri dari Society 5.0 Jepang. Publik Malaysia, India, dan Amerika Serikat memiliki rasa ingin tahu terhadap aspek masyarakat dan kebudayaan Jepang.

Hasil tren pencarian, penggunaan kata kunci, dan eksplorasi topik lain di Google dari publik Indonesia, Malaysia, India, dan Amerika Serikat dapat dikatakan beragam. Walaupun perhatian utama dari seluruh publik di empat negara adalah inovasi TIK dalam Society 5.0 Jepang, mereka juga memberikan perhatian pada aspek lain yang lebih spesifik seperti industri, bisnis, kesehatan, lingkungan, dan kebudayaan. Jika dikaitkan dengan hubungan antara globalisasi dan TIK maka keragaman tersebut hadir dari kondisi dan penggunaan TIK yang berbeda juga di tiap negara.

Persentase jumlah pengguna internet di dunia adalah $59 \%$ dari populasi. Dengan persentase tersebut, hanya India yang berada di bawah dengan 50\% dari populasi. Persentase pengguna internet di Indonesia, Malaysia, dan Amerika Serikat secara berturut-turut adalah $64 \%$, 83\%, dan $87 \%$ dari populasi masing-masing negara. Walaupun begitu, empat negara tersebut masih di bawah Jepang dengan persentase

\footnotetext{
$31 \&$ geo $=$ MY\&q=\%2Fg\%2F11fzkvd6z1 (diakses 6 Februari 2020).

${ }^{58}$ Google, "Explore Society 5.0 India 2019-01-01 to 2019-12-31," Google Trends, https://trends.google. com/trends/explore?date $=2019-01-01 \% 202019-12-$ $31 \&$ geo $=\mathrm{IN} \& \mathrm{q}=\% 2 \mathrm{Fg} \% \quad 2 \mathrm{~F} 11 \mathrm{fzkvd6z} 1$ (diakses 6 Februari 2020).

${ }^{59}$ Google, "Explore Society 5.0 United States 201901-01 to 2019-12-31," Google Trends, https://trends.google.com/trends/explore?date $=2019$ $-01-01 \% 202019-12-31 \&$ geo $=\mathrm{US} \& \mathrm{q}=\% 2 \mathrm{Fg} \% 2$ F11fzkvd6z1 (diakses 6 Februari 2020).
}

pengguna internet sebesar $92 \%$ dari populasi. Lebih lanjut, rata-rata kecepatan jaringan internet kabel di dunia sebesar 73,6 Megabit per second (Mbps). Indonesia dan India memiliki kecepatan internet kabel di bawah rata-rata dunia yaitu sebesar 13,8 Mbps dan 11,5 Mbps. Sedangkan Malaysia dan Amerika Serikat memiliki kecepatan internet kabel di atas rata-rata dunia yaitu 130,8 Mbps dan 78 Mbps. Rata-rata kecepatan jaringan internet kabel Jepang berada di bawah Amerika Serikat yaitu 104,6 Mbps. ${ }^{60}$

Persentase jumlah pengguna dan rata-rata kecepatan jaringan internet kabel Jepang dapat dikatakan unggul. Namun, Jepang menduduki posisi yang rendah dibandingkan Indonesia, Malaysia, India, dan Amerika Serikat dalam total waktu yang dihabiskan untuk mengakses internet per hari. Jepang menghabiskan 4 jam 22 menit. Sedangkan untuk empat negara tersebut adalah sebagai berikut: Indonesia 7 jam 59 menit, Malaysia 7 jam 57 menit, Amerika Serikat 6 jam 42 menit, dan India 6 jam 30 menit. Lebih lanjut, Indonesia dan Malaysia menghabiskan waktu mengakses internet per hari lebih besar dibandingkan rata-rata dunia. Rata-rata penduduk dunia menghabiskan waktu 6 jam 43 menit per hari untuk mengakses internet. ${ }^{61}$

Berbagai hasil penyebaran topik Society 5.0 Jepang melalui Google di publik Indonesia, Malaysia, India, dan Amerika Serikat yang sudah dibahas dapat dikatakan mendukung argumentasi Friedman mengenai globalisasi. Keberadaan aplikasi internet Google memungkinkan Jepang yang bukan negara dari benua Eropa dan Amerika mengglobal juga dengan visi Society 5.0. Lebih lanjut, kecenderungan dari penyebaran topik

\footnotetext{
${ }^{60} \mathrm{We}$ are Social, "Digital 2020: Global Digital Overview," Digital 2020: Global Digital Overview, https://wearesocial-net.s3-eu-west-

1.amazonaws.com/ wpcontent/uploads/common/reports/digital-2020/ digital-2020-global.pdf (diakses 12 Februari 2020). 61 Ibid.
} 
Muhammad Fikry Anshori | Globalisasi Society 5.0 Jepang: Studi Kasus Hasil

Pencarian Google di Luar Jepang Tahun 2019

Society 5.0 ini adalah kolaborasi global karena ketika Jepang menyebarkan Society 5.0 maka topik tersebut juga populer di Indonesia, Malaysia, dan Amerika Serikat. Publik di empat negara tersebut memberikan minat dan perhatian terhadap topik Society 5.0 Jepang. Mereka juga melakukan eksplorasi lebih lanjut terhadap topik Society 5.0 Jepang dengan pencarian topik lain yang dianggap terkait. Beragam hal tersebut berlangsung walaupun dengan kondisi dan penggunaan TIK yang berbeda di masing-masing negara. Sehingga benar karakteristik globalisasi saat ini menjadi lebih inklusif dengan keberadaan inovasi TIK berupa Google.

Wheeler dalam bukunya yang berjudul "From Gutenberg to Google: The History of Our Future" menyatakan inovasi TIK seperti internet adalah gaya pendorong yang mendefinisikan manusia. Perkembangan TIK dari waktu ke waktu akan semakin hebat. Masyarakat terlepas dari negara yang ditempatinya akan selalu merespon terhadap perkembangan tersebut. Oleh karena itu, perkembangan TIK seperti hadirnya Internet dan Google menjadi hal yang bersifat transformatif bagi manusia. Transformasi tersebut dapat berupa berbagai benda, jasa, atau pemikiran yang baru yang dapat menggeser, menggantikan, atau memperbarui yang lama. ${ }^{62}$ Argumen Wheeler dapat dikatakan mendukung karakteristik globalisasi yang dikenal saat ini didukung oleh perkembangan TIK terutama internet dan Google.

Penyebarluasan visi Society 5.0 di luar Jepang dengan Google memberikan keunggulan bagi Jepang dalam politik global. Dari pembahasan sebelumnya, Society 5.0 dapat dikatakan menjadi lebih dikenal dan didiskusikan di berbagai media massa negara lain. Hal tersebut tentu mendukung orientasi Pemerintah Jepang dalam menjalankan Society 5.0 yaitu menjadi percontohan bagi negara-negara

${ }^{62}$ T. Wheeler, From Gutenberg to Google: The History of Our Future, (Washington D.C.: The Brooking Institutions, 2019).

lain pada inovasi teknologi dan pembangunan ekonomi di tengah masalah sosial kontemporer. Matos et al dalam bukunya yang berjudul "Knowledge, People, and Digital Transformation: Approaches for a Sustainable Future" berpendapat Society 5.0 adalah transformasi digital unggulan karena menjanjikan kontribusi penting bagi masyarakat antara lain: 1) memfasilitasi penyelesaian masalah sosial, 2) mempercepat proses industrialisasi, 3) memperbaiki kualitas hidup masyarakat, serta 4) meratakan akses ilmu pengetahuan dan teknologi. ${ }^{63}$ Kontribusi demikian tentu menegaskan kapasitas Jepang untuk menjadi unggulan dalam pemanfaatan TIK.

\section{Kesimpulan}

Tujuan dari artikel ini adalah untuk menggambarkan penyebaran topik Society 5.0 Jepang di luar Jepang dengan mengangkat kasus hasil pencarian Google pada tahun 2019. Berdasarkan hasil pencarian Google, diketahui topik Society 5.0 Jepang menjadi perhatian publik asing di empat negara yaitu Indonesia, Malaysia, India, dan Amerika Serikat. Perhatian publik asing di empat negara tersebut terjadi tidak terlepas dari hubungan ekonomi yang mereka jalin dengan Jepang serta pemberitaan daring yang membahas beragam tema dan aspek dari Society 5.0 Jepang. Lebih lanjut, publik Indonesia, Malaysia, India, dan Amerika Serikat memiliki rasa ingin tahu juga terhadap topik Society 5.0 secara khusus dan Jepang secara umum. Mereka menelusuri aspek industri, masyarakat, dan kebudayaan Jepang. Keberagaman aspek tersebut dapat hadir karena perbedaan kondisi dan penggunaan teknologi informasi dan komunikasi (TIK) masing-masing negara. Berbagai karakteristik dari penyebaran topik Society 5.0 Jepang di luar Jepang yang sudah disebutkan memperlihatkan

${ }^{63}$ F. Matos et al, Knowledge, People, and Digital Transformation: Approaches for a Sustainable Future, (Switzerland: Springer Nature, 2020). 
Muhammad Fikry Anshori | Globalisasi Society 5.0 Jepang: Studi Kasus Hasil Pencarian Google di Luar Jepang Tahun 2019

kesesuaian argumentasi hubungan antara globalisasi dan TIK dari Thomas Friedman. Perkembangan globalisasi yang dialami oleh manusia di bumi tidak akan terlepas dan akan terus berpusat pada perkembangan TIK juga.

Artikel ini masih terbatas karena hanya menggambarkan kasus yang berlangsung secara singkat. Oleh karena itu, diperlukan kajian lebih lanjut untuk menggambarkan, menjelaskan, dan memahami globalisasi Society 5.0 Jepang dengan lebih lengkap. Terlebih, pengayaan dalam artikel ini memperlihatkan Society 5.0 adalah visi terkini Pemerintah Jepang untuk menjadi role model bagi dunia di bidang penggunaan TIK. Fenomena penyebaran visi pemerintah suatu negara terhadap publik negara lain untuk menjadi unggulan bisa dikaji dengan fokus pada kebijakan luar negeri, diplomasi, atau komunikasi media. Dengan kata lain, topik Society 5.0 Jepang masih memiliki banyak hal yang bisa dieksplorasi dalam Hubungan Internasional. 
Muhammad Fikry Anshori | Globalisasi Society 5.0 Jepang: Studi Kasus Hasil

Pencarian Google di Luar Jepang Tahun 2019

\section{DAFTAR PUSTAKA}

Aulia, T.. "Denna Rainyana: One Site for All Dutabisnis Jadi Solusi Layanan Korporasi untuk Society 5.0." Times Indonesia. https://www.timesindonesia.co.id/ $\mathrm{read} /$ news/228952/denna-rainyana-one-site-for-all-dutabisnis-jadi-solusi-layanankorporasi-untuk-society-50 (diakses 9 Februari 2020).

Bremmer, I. dan H. Nakanishi. "Critical for Japan to take global leadership role." The Japan News. https://the-japan-news.com/news/article/0006157173 (diakses 11 Februari 2020).

Central Intelligence Agency. "Japan." The World Factbook. https://www.cia.gov/library/ publications/the-world-factbook/geos/ja.html (diakses 3 Februari 2020).

Clark, D.. "An Insider's Guide to the Internet." MIT Computer Science and Artificial Intelligence Laboratory. https://groups.csail.mit.edu/ana/Publications/PubPDFs/AnInsiders-Guide-to-the-Internet.pdf (diakses 29 Januari 2020).

Diez, T., I. Bode, dan A.F. da Costa. Key Concepts in International Relations. London: SAGE, 2011.

Embassy of Japan in Malaysia. "Overview of Japan-Malaysia Relationship." Embassy of Japan in Malaysia. https://www.my.emb-japan.go.jp/English/bilateral/ Overview_bilateral.htm (diakses 8 Februari 2020).

Fitria, A.. "Ketua Aspikom: Manusia Saat Ini Terbagi Jadi Dua Kelompok." IDN Times. https://www.idntimes.com/news/indonesia/aulia-fitria/ketua-aspikom-manusia-saat-initerbagi-jadi-dua-kelompok/full (diakses 9 Februari 2020).

Friedman, T. L.. The World is Flat: A Brief History of the Twenty-First Century. New York: Picador, 2007.

Fukuda, K.. "Science, technology and innovation ecosystem transformation toward society 5.0." International Journal of Production Economics (2019): https://doi.org/10.1016/j.ijpe.2019.07.033.

Gerring, J.. "What is Case Study and What Is It Good for?." American Political Science Review 40, no. 3 (2004): 341-354.

Gilpin, R.. Global Political Economy. Princeton: Princeton Press, 2001.

Gladden, M. E.. "Who Will Be the Members of Society 5.0? Towards an Anthropology of Technologically Posthumanized Future Societies." Social Sciences 8, no. 5 (2019): 148.

Global Knowledge. "Smartphone Explained." MicroComputer Resources. http://www. mcrinc.com/Documents/Newsletters/201104_Hill_Smartphones.pdf (diakses 30 Januari 2020).

Google. "The Homepage Explained." Google Support. https://support.google.com/trends/ answer/6248105?hl=en\&ref_topic=6248052 (diakses 28 Januari 2020).

Google. "Explore Society 5.0 Worldwide 2019-01-01 to 2019-12-31." Google Trends. https://trends.google.com/trends/explore?date=2019-01-01\%202019-12-31\& $\mathrm{q}=\% 2 \mathrm{Fg} \% 2 \mathrm{~F} 11 \mathrm{fzkvd} 6 \mathrm{z} 1$ (diakses 6 Februari 2020).

Google. "multiTimeline India." Google Trends. https://trends.google.com/trends/api/ widgetdata/multiline/csv?req=\%7B\%22time\%22\%3A\%222019-01-01\%202019-12$31 \% 22 \% 2 \mathrm{C} \% 22$ resolution $\% 22 \% 3 \mathrm{~A} \% 22 \mathrm{WEEK} \% 22 \% 2 \mathrm{C} \% 22$ locale $\% 22 \% 3 \mathrm{~A} \% 22 \mathrm{en}-$ US $\% 22 \% 2 \mathrm{C} \% 22$ comparisonItem $\% 22 \% 3 \mathrm{~A} \% 5 \mathrm{~B} \% 7 \mathrm{~B} \% 22$ geo $\% 22 \% 3 \mathrm{~A} \% 7 \mathrm{~B} \% 22$ country $\% 22 \% 3 \mathrm{~A} \% 22 \mathrm{IN} \% 22 \% 7 \mathrm{D} \% 2 \mathrm{C} \% 22$ complexKeywordsRestriction $\% 22 \% 3 \mathrm{~A} \% 7 \mathrm{~B} \% 22 \mathrm{key}$ word $\% 22 \% 3 \mathrm{~A} \% 5 \mathrm{~B} \% 7 \mathrm{~B} \% 22$ type $\% 22 \% 3 \mathrm{~A} \% 22 \mathrm{ENTITY} \% 22 \% 2 \mathrm{C} \% 22$ value $\% 22 \% 3 \mathrm{~A} \%$ $22 \% 2 \mathrm{Fg} \% 2 \mathrm{~F} 11$ fzkvd6z1\%22\%7D $\% 5 \mathrm{D} \% 7 \mathrm{D} \% 7 \mathrm{D} \% 5 \mathrm{D} \% 2 \mathrm{C} \% 22$ requestOptions $\% 22 \% 3$ A\%7B \%22property $\% 22 \% 3 \mathrm{~A} \% 22 \% 22 \% 2 \mathrm{C} \% 22$ backend $\% 22 \% 3 \mathrm{~A} \% 22 \mathrm{IZG} \% 22 \% 2 \mathrm{C} \% 22$ 
Muhammad Fikry Anshori | Globalisasi Society 5.0 Jepang: Studi Kasus Hasil

Pencarian Google di Luar Jepang Tahun 2019

category\%22\%3A0\%7D\%7D\&token=APP6_UEAAAAAXj0aWEEJbKMpwaN4CcjMy

KTPOPCkY9vX\&tz=-420 (diakses 6 Februari 2020).

Google. "multiTimeline Indonesia." Google Trends. https://rends.google.com/trends/api/ widgetdata/multiline/csv?req=\%7B\%22time\%22\%3A\%222019-01-01\%202019-12-

$31 \% 22 \% 2 \mathrm{C} \% 22$ resolution $\% 22 \% 3 \mathrm{~A} \% 22 \mathrm{WEEK} \% 22 \% 2 \mathrm{C} \% 22$ locale $\% 22 \% 3 \mathrm{~A} \% 22 \mathrm{en}-$ US $\% 22 \% 2 \mathrm{C} \% 22$ comparisonItem $\% 22 \% 3 \mathrm{~A} \% 5 \mathrm{~B} \% 7 \mathrm{~B} \% 22 \mathrm{geo} \% 22 \% 3 \mathrm{~A} \% 7 \mathrm{~B} \% 22$ country $\% 22 \% 3 \mathrm{~A} \% 22 \mathrm{ID} \% 22 \% 7 \mathrm{D} \% 2 \mathrm{C} \% 22$ complexKeywordsRestriction $\% 22 \% 3 \mathrm{~A} \% 7 \mathrm{~B} \% 22 \mathrm{key}$ word $\% 22 \% 3 \mathrm{~A} \% 5 \mathrm{~B} \% 7 \mathrm{~B} \% 22$ type $\% 22 \% 3 \mathrm{~A} \% 22 \mathrm{ENTITY} \% 22 \% 2 \mathrm{C} \% 22$ value $\% 22 \% 3 \mathrm{~A} \%$ 22\%2Fg\%2F11fzkvd6z1\%22\%7D\%5D\%7D\%7D\%5D\%2C\%22requestOptions\%22\%3 A\%7B \%22property\%22\%3A\%22\%22\%2C\%22backend\%22\%3A\%22IZG\%22\%2C\%22 category\%22\%3A0\%7D\%7D\&token=APP6_UEAAAAAXj0SkLU1YMnAT9hkPhkHy noFtTL9y951\&tz=-420 (diakses 6 Februari 2020).

Google. "multiTimeline Malaysia." Google Trends. https://trends.google.com/trends/api/ widgetdata/multiline/csv?req=\%7B\%22time\%22\%3A\%222019-01-01\%202019-12$31 \% 22 \% 2 \mathrm{C} \% 22$ resolution $\% 22 \% 3 \mathrm{~A} \% 22 \mathrm{WEEK} \% 22 \% 2 \mathrm{C} \% 22$ locale $\% 22 \% 3 \mathrm{~A} \% 22 \mathrm{en}-$ US $\% 22 \% 2 \mathrm{C} \% 22$ comparisonItem $\% 22 \% 3 \mathrm{~A} \% 5 \mathrm{~B} \% 7 \mathrm{~B} \% 22 \mathrm{geo} \% 22 \% 3 \mathrm{~A} \% 7 \mathrm{~B} \% 22$ country $\% 22 \% 3 \mathrm{~A} \% 22 \mathrm{MY} \% 22 \% 7 \mathrm{D} \% 2 \mathrm{C} \% 22$ complexKeywordsRestriction\%22\%3A\%7B\%22ke yword $\% 22 \% 3 \mathrm{~A} \% 5 \mathrm{~B} \% 7 \mathrm{~B} \% 22$ type $\% 22 \% 3 \mathrm{~A} \% 22 \mathrm{ENTITY} \% 22 \% 2 \mathrm{C} \% 22$ value $\% 22 \% 3 \mathrm{~A}$ $\% 22 \% 2 \mathrm{Fg} \% 2 \mathrm{~F} 11 \mathrm{fzkvd6z} 1 \% 22 \% 7 \mathrm{D} \% 5 \mathrm{D} \% 7 \mathrm{D} \% 7 \mathrm{D} \% 5 \mathrm{D} \% 2 \mathrm{C} \% 22$ requestOptions $\% 22 \%$ $3 \mathrm{~A} \% 7 \mathrm{~B} \% 22$ property $\% 22 \% 3 \mathrm{~A} \% 22 \% 22 \% 2 \mathrm{C} \% 22$ backend $\% 22 \% 3 \mathrm{~A} \% 22 \mathrm{IZG} \% 22 \% 2 \mathrm{C} \% 2$ 2category\%22\%3A0\%7D\%7D\&token=APP6_UEAAAAAXj0Y40o_3qFByOuK0oXkjx mpuCucCVU4\&tz=-420 (diakses 6 Februari 2020).

Google. "multiTimeline United States." Google Trends. https://trends.google.com/trends/api/ widgetdata/multiline/csv?req=\%7B\%22time\%22\%3A\%222019-01-01\%202019-12$31 \% 22 \% 2 \mathrm{C} \% 22$ resolution $\% 22 \% 3 \mathrm{~A} \% 22 \mathrm{WEEK} \% 22 \% 2 \mathrm{C} \% 22$ locale $\% 22 \% 3 \mathrm{~A} \% 22 \mathrm{en}-$ US $\% 22 \% 2 \mathrm{C} \% 22$ comparisonItem $\% 22 \% 3 \mathrm{~A} \% 5 \mathrm{~B} \% 7 \mathrm{~B} \% 22 \mathrm{geo} \% 22 \% 3 \mathrm{~A} \% 7 \mathrm{~B} \% 22$ country $\% 22 \% 3 \mathrm{~A} \% 22 \mathrm{US} \% 22 \% 7 \mathrm{D} \% 2 \mathrm{C} \% 22$ complexKeywordsRestriction\%22\%3A\%7B\%22key word $\% 22 \% 3 \mathrm{~A} \% 5 \mathrm{~B} \% 7 \mathrm{~B} \% 22$ type $\% 22 \% 3 \mathrm{~A} \% 22 \mathrm{ENTITY} \% 22 \% 2 \mathrm{C} \% 22$ value $\% 22 \% 3 \mathrm{~A} \%$ 22\%2Fg\%2F11fzkvd6z1\%22\%7D\%5D\%7D\%7D\%5D\%2C\%22requestOptions\%22\%3 A\%7B\%22property\%22\%3A\%22\%22\%2C\%22backend\%22\%3A\%22IZG\%22\%2C\%22 category\%22\%3A0\%7D\%7D\&token=APP6_UEAAAAAXj0cQzTghM4ezA112sS03Y XbbpmFxjYr\&tz=-420 (diakses 6 Februari 2020).

Google. "geoMap Worldwide." Google Trends. https://trends.google.com/trends/api/ widgetdata/comparedgeo/csv?req $=\% 7 \mathrm{~B} \% 22 \mathrm{geo} \% 22 \% 3 \mathrm{~A} \% 7 \mathrm{~B} \% 7 \mathrm{D} \% 2 \mathrm{C} \% 22$ comparison Item $\% 22 \% 3 \mathrm{~A} \% 5 \mathrm{~B} \% 7 \mathrm{~B} \% 22$ time $\% 22 \% 3 \mathrm{~A} \% 222019-01-01 \% 202019-12-$

$31 \% 22 \% 2 \mathrm{C} \% 22$ complexKeywordsRestriction $\% 22 \% 3 \mathrm{~A} \% 7 \mathrm{~B} \% 22 \mathrm{keyword} \% 22 \% 3 \mathrm{~A} \% 5 \mathrm{~B}$ $\% 7 \mathrm{~B} \% 22$ type $\% 22 \% 3 \mathrm{~A} \% 22 \mathrm{ENTITY} \% 22 \% 2 \mathrm{C} \% 22$ value $\% 22 \% 3 \mathrm{~A} \% 22 \% 2 \mathrm{Fg} \% 2 \mathrm{~F} 11 \mathrm{fzkv}$ d6z1\%22\%7D\%5D\%7D\%7D\%5D\%2C\%22resolution\%22\%3A\%22COUNTRY\%22\%2 C\%22locale $\% 22 \% 3 \mathrm{~A} \% 22 \mathrm{en}-\mathrm{US} \% 22 \% 2 \mathrm{C} \% 22$ requestOptions $\% 22 \% 3 \mathrm{~A} \% 7 \mathrm{~B} \% 22$ property $\% 22 \% 3 \mathrm{~A} \% 22 \% 22 \% 2 \mathrm{C} \% 22$ backend $\% 22 \% 3 \mathrm{~A} \% 22 \mathrm{IZG} \% 22 \% 2 \mathrm{C} \% 22$ category $\%$ 22\%3A0\%7D\%2C\%22includeLowSearchVolumeGeos\%22\%3Atrue\%7D\&token=APP6 _UEAAAAAXj0ID2qm9I6xo1KzY8Vb1549ILaiXxFM\&tz=-420 (diakses 6 Februari 2020).

Google. "relatedQueries Indonesia." Google Trends. https://rends.google.com/trends/api/ widgetdata/relatedsearches/csv?req $=\% 7 \mathrm{~B} \% 22$ restriction $\% 22 \% 3 \mathrm{~A} \% 7 \mathrm{~B} \% 22 \mathrm{geo} \% 22 \% 3 \mathrm{~A}$ $\% 7 \mathrm{~B} \% 22$ country\%22\%3A\%22ID\%22\%7D\%2C\%22time\%22\%3A\%222019-0101\%202019-12-31\%22\%2C\%22originalTimeRangeForExploreUrl\%22\%3A\%22201901-01\%202019-12-31\%22\%2C\%22complexKeywordsRestriction\%22\%3A\%7B\%22 keyword $\% 22 \% 3 \mathrm{~A} \% 5 \mathrm{~B} \% 7 \mathrm{~B} \% 22$ type $\% 22 \% 3 \mathrm{~A} \% 22 \mathrm{ENTITY} \% 22 \% 2 \mathrm{C} \% 22$ value $\% 22 \% 3$ 
Muhammad Fikry Anshori | Globalisasi Society 5.0 Jepang: Studi Kasus Hasil

Pencarian Google di Luar Jepang Tahun 2019

A\%22\%2Fg\%2F11fzkvd6z1\%22\%7D\%5D\%7D\%7D\%2C\%22keywordType $\% 22 \% 3 \mathrm{~A} \%$ 22QUERY\%22\%2C\%22metric\%22\%3A\%5B\%22TOP\%22\%2C\%22RISING\%22\%5D

$\% 2 \mathrm{C} \% 22$ trendinessSettings\%22\%3A\%7B\%22compareTime\%22\%3A\%222018-01-

01\%202018-12-31\%22\%7D\%2C\%22requestOptions\%22\%3A\%7B\%22

property $\% 22 \% 3 \mathrm{~A} \% 22 \% 22 \% 2 \mathrm{C} \% 22$ backend $\% 22 \% 3 \mathrm{~A} \% 22 \mathrm{IZG} \% 22 \% 2 \mathrm{C} \% 22$ category $\%$

$22 \% 3 \mathrm{~A} 0 \% 7 \mathrm{D} \% 2 \mathrm{C} \% 22$ language $\% 22 \% 3 \mathrm{~A} \% 22 \mathrm{en} \% 22 \% 7 \mathrm{D} \&$ token=APP6_UEAAAAAX j2DFfng2gofcBrLOABLZD3oikIfFPLw\&tz=-420 (diakses 6 Februari 2020).

Google. "relatedQueries Malaysia." Google Trends. https://trends.google.com/trends/api/ widgetdata/relatedsearches/csv?req $=\% 7 \mathrm{~B} \% 22$ restriction $\% 22 \% 3 \mathrm{~A} \% 7 \mathrm{~B} \% 22 \mathrm{geo} \% 22 \% 3 \mathrm{~A}$ $\% 7 \mathrm{~B} \% 22$ country\%22\%3A\%22MY\%22\%7D\%2C\%22time\%22\%3A\%222019-01-

01\%202019-12-31\%22\%2C\%22originalTimeRangeForExploreUrl\%22\%3A\%222019-

01-01\%202019-12-31\%22\%2C\%22complexKeywords

Restriction $\% 22 \% 3 \mathrm{~A} \% 7 \mathrm{~B} \% 22 \mathrm{keyword} \% 22 \% 3 \mathrm{~A} \% 5 \mathrm{~B} \% 7 \mathrm{~B} \% 22$ type $\% 22 \% 3 \mathrm{~A} \% 22 \mathrm{ENTIT}$ Y\%22\%2C\%22value\%22\%3A\%22\%2Fg\%2F11fzkvd6z1\%22\%7D\%5D\%7D\%7D\%2C \%22keywordType $\% 22 \% 3 \mathrm{~A} \% 22 \mathrm{QUERY} \% 22 \% 2 \mathrm{C} \% 22$ metric $\% 22 \% 3 \mathrm{~A} \% 5 \mathrm{~B} \% 22 \mathrm{TOP} \% 2$ 2\%2C\%22RISING\%22\%5D\%2C\%22trendinessSettings\%22\%3A\%7B\%22compareTim e\%22\%3A\%222018-01-01\%202018-12-31\%22\%7D\%2C\%22request

Options $\% 22 \% 3 \mathrm{~A} \% 7 \mathrm{~B} \% 22$ property $\% 22 \% 3 \mathrm{~A} \% 22 \% 22 \% 2 \mathrm{C} \% 22$ backend $\% 22 \% 3 \mathrm{~A} \% 22 \mathrm{IZ}$ G\%22\%2C\%22category\%22\%3A0\%7D\%2C\%22language $\% 22 \% 3 \mathrm{~A} \% 22 \mathrm{en} \% 22 \% 7 \mathrm{D} \&$ to ken=APP6_UEAAAAAXj2DfugxNCedRG49U3fyKPyp96cAH3dw\&tz=-420 (diakses 6 Februari 2020).

Google. "Explore Society 5.0 Indonesia 2019-01-01 to 2019-12-31." Google Trends. https://trends.google.com/trends/explore?date=2019-01-01\%202019-12-31\&geo=ID\& $\mathrm{q}=\% 2 \mathrm{Fg} \% 2 \mathrm{~F} 11 \mathrm{fzkvd6z1}$ (diakses 6 Februari 2020).

Google. "Explore Society 5.0 Malaysia 2019-01-01 to 2019-12-31." Google Trends. https://trends.google.com/trends/explore?date=2019-01-01\%202019-12-31\&geo=MY\& $\mathrm{q}=\% 2 \mathrm{Fg} \% 2 \mathrm{~F} 11 \mathrm{fzkvd6z1}$ (diakses 6 Februari 2020).

Google. "Explore Society 5.0 India 2019-01-01 to 2019-12-31." Google Trends. https://trends.google.com/trends/explore?date=2019-01-01\%202019-12-31\&geo=IN\& $\mathrm{q}=\% 2 \mathrm{Fg} \%$ 2F11fzkvd6z1 (diakses 6 Februari 2020).

Google. "Explore Society 5.0 United States 2019-01-01 to 2019-12-31." Google Trends. https://trends.google.com/trends/explore?date=2019-01-01\%202019-12-31\&geo=US\& $\mathrm{q}=\% 2 \mathrm{Fg} \% 2 \mathrm{~F} 11 \mathrm{fzkvd6z1}$ (diakses 6 Februari 2020).

Government of Japan. "Realizing Society 5.0." The Government of Japan. https://www.japan.go.jp/abenomics/_userdata/abenomics/pdf/society_5.0.pdf (diakses 3 Februari 2020).

Government of Japan. "Technology." The Government of Japan. https://www.japan.go.jp/technology/ (diakses 19 Juni 2020).

Held, D., A. McGrew, D. Goldblatt, dan J. Perraton. Global Transformations: Politics, Economics and Culture. Cambridge: Polity Press, 1999.

International Telecommunication Union. Measuring Digital Development: Facts and Figure 2019. Geneva: ITU Publications, 2019.

InternetLiveStats. "Google Search Statistics." Internet Live Stats. https://internetlivestats. com/google-search-statistics (diakses 30 Januari 2020).

Japan Brandvoice. "Society 5.0 Town Turns Heads At Japan's CEATEC Tech Show." Forbes. https://www.forbes.com/sites/japan/2019/11/28/society-50-town-turns-heads-atjapans-ceatec-tech-show/\#2c1ca01d542f (diakses 11 Februari 2020).

Jones, A.. Globalization: Key Thinkers. Cambridge: Polity Press, 2010. 
Muhammad Fikry Anshori | Globalisasi Society 5.0 Jepang: Studi Kasus Hasil

Pencarian Google di Luar Jepang Tahun 2019

Kafle, V. P.. "Toward Society 5.0.” myRepublica. https://myrepublica.nagariknetwork.com/ news/toward-society-5-0/ (diakses 11 Februari 2020).

Kedutaan Besar Jepang di Indonesia. "Hubungan Bilateral Indonesia-Jepang." Kedutaan Besar Jepang di Indonesia. https://www.id.emb-japan.go.jp/birel_id.html (diakses 8 Februari 2020).

Kumar, S.. "Deploy science now to reach sustainable growth goals." New Straits Times. https://www.nst.com.my/opinion/columnists/2019/07/508534/deploy-science-now-reachsustainable-growth-goals (diakses 9 Februari 2020).

Manning, J.. "Social Media, Definition and Classes of." Dalam Encyclopedia of Social Media and Politics, diedit oleh K. Harvey, 1158-1162. Thousand Oaks: SAGE, 2014.

Matos, F., Vairinhos, V., Salavis, I., Edvinsson, L., \& Massaro, M.. Knowledge, People, and Digital Transformation: Approaches for a Sustainable Future. Switzerland: Springer Nature, 2020.

Matsuda, K., S. Uesugi, K. Naruse, dan M. Morita. "Technologies of Production with Society 5.0." 2019 6th International Conference on Behavioral, Economic and Socio-Cultural Computing (BESC) (2019): 10.1109/BESC48373.2019.8963541.

Mayasari, D.. "Mengenal Society 5.0, Transformasi Kehidupan yang Dikembangkan Jepang." Times Indonesia. https://www.timesindonesia.co.id/read/news/197889/ mengenal-society-50-transformasi-kehidupan-yang-dikembangkan-jepang (diakses 9 Februari 2020).

Minevich, M.. "Japan's 'Society 5.0' initiative is a road map for today's entrepreneurs." TechCrunch. $\quad$ https://techcrunch.com/2019/02/02/japans-society-5-0-initiative-is-aroadmap-for-todays-entrepreneurs/ (diakses 11 Februari 2020).

Ministry of Foreign Affairs of Japan. "Diplomatic Bluebook 2019." Diplomatic Bluebook, https://www.mofa.go.jp/files/000527162.pdf (diakses 8 Februari 2020).

Ministry of Foreign Affairs of Japan. "Speech by Prime Minister Abe at the World Economic Forum Annual Meeting Toward a New Era of "Hope-Driven Economy" (23 January 2019)" Ministry of Foreign Affairs of Japan. https://www.mofa.go.jp/ecm/ec/ page4e_000973.html (diakses 3 Februari 2020).

Ministry of Foreign Affairs of Japan. "Exchange of Notes in Fiscal Year 2019: Grant Aid by Region." Ministry of Foreign Affairs of Japan. https://www.mofa.go.jp/policy/oda/ page22e_000878.html (diakses 8 Februari 2020).

Ministry of Foreign Affairs of Japan. "Exchange of Notes in Fiscal Year 2019: Loan Aid by Region." Ministry of Foreign Affairs of Japan. https://www.mofa.go.jp/policy/ oda/page22e_000891.html (diakses 8 Februari 2020).

Ministry of Foreign Affairs of Japan. "Japan-India Relations." Ministry of Foreign Affairs of Japan. https://www.mofa.go.jp/region/asia-paci/india/data.html (diakses 8 Februari 2020).

Ministry of Foreign Affairs of Japan. "Japan-United States of America Relations." Ministry of Foreign Affairs of Japan. https://www.mofa.go.jp/na/na1/us/page23e_000329.html (diakses 8 Februari 2020).

Ministry of Foreign Affairs of Japan. "Is it true that Japan imports only agricultural products from the United States?." Ministry of Foreign Affairs of Japan. https://www.mofa.go.jp/region/n-america/us/q\&a/trend/3.html (diakses 8 Februari 2020).

Ministry of Foreign Affairs of Japan. "Japanese industries have been setting up a lot of companies in the United States. Do they benefit the U.S. economy?." Ministry of Foreign Affairs of Japan. https://www.mofa.go.jp/region/n-america/us/q\&a/trend/ 5.html (diakses 8 Februari 2020). 
Muhammad Fikry Anshori | Globalisasi Society 5.0 Jepang: Studi Kasus Hasil

Pencarian Google di Luar Jepang Tahun 2019

McGrew, A.. "Globalization and Global Politics." Dalam The Globalization of World Politics: An Introduction to International Relations, diedit oleh J. Baylis, S. Smith, P. Owens, 16-31. New York: Oxford University Press, 2014.

Nagahara, M.. "A Research Project of Society 5.0 in Kitakyushu, Japan." 2019 IEEE Conference on Control Technology and Applications (CCTA) (2019): 10.1109/CCTA.2019.8920449.

Onday, O.. "Japan's Society 5.0: Going Beyond Industry 4.0." Business and Economics Journal 10, no 2. (2019): 389.

Oracle. "What is Big Data?." Oracle. https://www. oracle.com/big-data/guide/what-is-bigdata.html (diakses 30 Januari 2020).

Our Bureau. "Japan throws open doors of manufacturing, healthcare sectors for Indian firms." The Hindu Business Line, https://www. thehindubusinessline.com/companies/japan-throws-open-doors-of-manufacturinghealthcare-sectors-for-indian-firms/article26472642.ece (diakses 11 Februari 2020).

Outline World Map. "Outline World Map Images." Outline World Map, http://www.outlineworld-map.com/political-outline-world-map-b10a (diakses 8 Februari 2020).

Pareira, A. G. dan T. M. Lima. "Society 5.0 as a Result of the Technological Evolution: Historical Approach." International Conference on Human Interaction and Emerging Technologies (2019): 700-705.

Patel, K. K. dan S. M. Patel. "Internet of Things-IOT: Definition, Characteristics, Architecture, Enabling Technologies, Application \& Future Challenges." International Journal of Engineering Science and Computing 6. No. 5 (2016): 6122-6131.

Prima, E.. "BPPT Berharap Forum ASEAN Jadi Momentum Open Government dan Data." Teтро. https://tekno.tempo.co/read/1275090/bppt-berharap-forum-asean-jadimomentum-open-government-dan-data/full\&view=ok (diakses 9 Februari 2020).

Ritzer, G. dan P. Dean. Globalization: A Basic Text. Oxford: John Wiley \& Sons, 2015.

Rozana, S. dan Z. Mustafa. "What lies ahead in 2019 for higher education?." New Straits Times. $\quad$ https://www.nst.com.my/education/2019/01/446228/what-lies-ahead-2019higher-education (diakses 9 Februari 2020).

Santoso, W. B.. "Jelajahi Era 5.0, Jepang Sudah Lama Tinggalkan Industri 4.0." Sindo News. https://autotekno.sindonews.com/read/1374004/207/jelajahi-era-50-jepang-sudah-lamatinggalkan-industri-40-1548594777 (diakses 9 Februari 2020).

Salgues, B.. Society 5.0: Industry of the Future, Technologies, Methods and Tools. Hoboken: John Wiley \& Sons, 2018.

Scholte, J. A.. Globalization: A Critical Introduction. New York: Palgrave Macmillan, 2005.

Schwab, K.. The Fourth Industrial Revolution. (Geneva: World Economic Forum).

Shiroishi, Y., K. Uchiyama, dan N. Suzuki. "Better Actions for Society 5.0: Using AI for Evidence-Based Policy Making That Keeps Humans in the Loop." Computer 52, no 11 (2019): 73-78.

The Sun Daily. "Of collaborations and insights: Industry Insights 2019 themed Advocates of Society 5.0." The Sun Daily. https://www.thesundaily.my/supplement/education/ofcollaborations-and-insights-YN1179652 (diakses 9 Februari 2020).

UNESCO. "Japan pushing ahead with Society 5.0 to overcome chronic social challenges." UNESCO. $\quad$ https://en.unesco.org/news/japan-pushing-ahead-society-50-overcomechronic-social-challenges (diakses 3 Februari 2020).

Vise, D. A.. The Google Story: Inside the Hottest Business, Media, and Technology Success of Our Time. London: Pan Macmillan, 2005.

Wang, P.. "What do You Mean by "AI"?," Frontiers in Artificial Intelligence and Applications (2008): 362-373. 
Muhammad Fikry Anshori | Globalisasi Society 5.0 Jepang: Studi Kasus Hasil

Pencarian Google di Luar Jepang Tahun 2019

We are Social. "Digital 2020: Global Digital Overview." Digital 2020: Global Digital Overview. https://wearesocial-net.s3-eu-west-1.amazonaws.com/wp-content/uploads/ common/reports/digital-2020/digital-2020-global.pdf (diakses 12 Februari 2020).

Wheeler, T.. From Gutenberg to Google: The History of Our Future. Washington D.C.: The Brooking Institutions, 2019.

Winosa, Y.. "Bangun SDM Industri Kompeten, Kemenperin Dorong Kualitas Institut." Warta Ekonomi. https://www.wartaekonomi.co.id/read246639/bangun-sdm-industrikompeten-kemenperin-dorong-kualitas-institut (diakses 9 Februari 2020).

Yamaguchi, S.. "Collaboration among stakeholders key to achieving development goals." Nikkei Asian Review. https://asia.nikkei.com/Opinion/Collaboration-among-stakeholderskey-to-achieving-development-goals (diakses 11 Februari 2020).

Yee, T. J.. "Wild Digital 2019: Mindful Entrepreneurs Can Catalyze Great Change.” Digital News Asia. https://www.digitalnewsasia.com/digital-economy/wild-digital-2019mindful-entrepreneurs-can-catalyse-great-change (diakses 9 Februari 2020).

Yin, R. K.. Case Study Research and Application: Designs and Methods. London: SAGE, 2018. 